\title{
Fibroblast growth factors as tissue repair and regeneration therapeutics
}

Quentin M Nunes, Yong Li, Changye Sun, Tarja K Kinnunen, David G Fernig

Cell communication is central to the integration of cell function required for the development and homeostasis of multicellular animals. Proteins are an important currency of cell communication, acting locally (auto-, juxta-, or paracrine) or systemically (endocrine). The fibroblast growth factor (FGF) family contributes to the regulation of virtually all aspects of development and organogenesis, and after birth to tissue maintenance, as well as particular aspects of organism physiology. In the West, oncology has been the focus of translation of FGF research, whereas in China and to an extent Japan a major focus has been to use FGFs in repair and regeneration settings. These differences have their roots in research history and aims. The Chinese drive into biotechnology and the delivery of engineered clinical grade FGFs by a major Chinese research group were important enablers in this respect. The Chinese language clinical literature is not widely accessible. To put this into context, we provide the essential molecular and functional background to the FGF communication system covering FGF ligands, the heparan sulfate and Klotho co-receptors and FGF receptor (FGFR) tyrosine kinases. We then summarise a selection of clinical reports that demonstrate the efficacy of engineered recombinant FGF ligands in treating a wide range of conditions that require tissue repair / regeneration. Alongside, the functional reasons why application of exogenous FGF ligands does not lead to cancers are described. Together, this highlights that the FGF ligands represent a major opportunity for clinical translation that has been largely overlooked in the West. 


\section{Fibroblast growth factors as tissue repair and regeneration therapeutics} 2

3 Quentin M. Nunes ${ }^{1}$, Yong $\mathrm{Li}^{2}$, Changye $\mathrm{Sun}^{2}$, Tarja K. Kinnunen ${ }^{3}$, David G. Fernig²

$4 \quad{ }^{1}$ Department of Molecular and Clinical Cancer Medicine, NIHR Liverpool Pancreas Biomedical

5 Research Unit, University of Liverpool, Liverpool L69 3GA, United Kingdom

6

$7 \quad{ }^{2}$ Department of Biochemistry, Institute of Integrative Biology, University of Liverpool,

8 Liverpool L69 7ZB, United Kingdom

9

$10{ }^{3}$ Department of Biology, School of Applied Sciences, University of Huddersfield, Huddersfield 11 HD1 3DH, United Kingdom 


\section{Abstract}

13 Cell communication is central to the integration of cell function required for the 14 development and homeostasis of multicellular animals. Proteins are an important currency 15 of cell communication, acting locally (auto-, juxta-, or paracrine) or systemically 16 (endocrine). The fibroblast growth factor (FGF) family contributes to the regulation of 17 virtually all aspects of development and organogenesis, and after birth to tissue 18 maintenance, as well as particular aspects of organism physiology. In the West, oncology has been the focus of translation of FGF research, whereas in China and to an extent Japan a major focus has been to use FGFs in repair and regeneration settings. These differences 21 have their roots in research history and aims. The Chinese drive into biotechnology and the 22 delivery of engineered clinical grade FGFs by a major Chinese research group were 23 important enablers in this respect. The Chinese language clinical literature is not widely 24 accessible. To put this into context, we provide the essential molecular and functional 25 background to the FGF communication system covering FGF ligands, the heparan sulfate 26 and Klotho co-receptors and FGF receptor (FGFR) tyrosine kinases. We then summarise a 27 selection of clinical reports that demonstrate the efficacy of engineered recombinant FGF 28 ligands in treating a wide range of conditions that require tissue repair / regeneration. 29 Alongside, the functional reasons why application of exogenous FGF ligands does not lead to cancers are described. Together, this highlights that the FGF ligands represent a major opportunity for clinical translation that has been largely overlooked in the West. 


\section{Overview}

33 In unicellular organisms the unit of natural selection is the cell, whereas in multicellular animals 34 natural selection operates on the organism. This is a very profound difference. The driver is 35 likely to have been simple: there is a limit on the complexity of an individual cell, beyond which 36 it is no longer robust. However, greater organism complexity allows new ecological niches and 37 lifestyles to be exploited. Natural selection has given rise to multicellularity and cell specialisation, as a means to allow a high level of organism complexity in concert with simple and robust cells. This requires a deep functional integration of cells in the organism, achieved through cell communication, which occurs by cells delivering information through the synthesis and secretion of signalling molecules into the extracellular space; these then elicit signals in cells possessing appropriate receptor systems. The entire biochemical landscape, from ions and small molecules to proteins and polysaccharides is used to generate the repertoire of signalling molecules.

In multicellular animals, proteins are common currency in cell communication and are used to transmit information between cells in the organism both locally (intra-, auto-, juxta- and paracrine) and systemically (endocrine). Local transmission of information may be mediated by a soluble, secreted protein, or by a protein anchored in the extracellular matrix or on the plasma membrane of a neighbouring cell. The exploitation of proteins for cell communication by multicellular animals provides access to a very subtle language. This subtlety arises in part from the fact that an individual protein species may have many different isoforms (from splice variants to glycoforms), localisations and interacting partners. Each subset of molecular interactions that an individual protein species can partake in may elicit completely different, sometimes opposing, cellular responses, and, moreover, may change the distance over which communication occurs, e.g., paracrine versus endocrine.

Most therapeutics can be considered to manipulate cell communication, with varying aims, such as reducing overactive communication channels in cancer and inflammatory diseases, or increasing particular channels of communication for tissue repair and regeneration. Clearly, manipulating cell communication therapeutically is not without danger, since the opposite of the desired effect may occur. Less obvious, but an important focus of this review, is that the drivers

61 of scientific discovery can narrow dramatically how a particular communication system is used

62 clinically. This is exemplified by the fibroblast growth factor (FGF) family, which contributes to 
63 the regulation of virtually all aspects of development and organogenesis, and after birth in many 64 natural processes of tissue repair and the endocrine regulation of particular facets of organism 65 physiology. In the West, the major focus of clinical translation has been on developing inhibitors 66 of FGF-mediated cell communication for use in cancer therapy. In the East, particularly in China 67 and to an extent in Japan, a major focus has been to use FGFs in regenerative/repair medical settings, differences that have their roots in a combination of research history and research aims. To increase awareness of this work, we summarise a number of published clinical reports to illustrate the breadth and depth of the successful clinical applications of FGFs.

\section{The discovery of FGF ligands and their activities}

Historically, the growth factor activity was the first to be identified. In hindsight, the paper of Trowell and Wilmer, which measured the mitogenic activity of saline extracts of different tissues from the chick can be considered to be the first FGF paper (Trowell \& Willmer 1939) - the activity they isolated from brain would consist of FGF-1, FGF-2 (Burgess \& Maciag 1989), as well as other growth factors active on fibroblasts, e.g., pleiotrophin (Courty et al. 1991), and that from other tissues largely FGF-2 (Burgess \& Maciag 1989; Fernig \& Gallagher 1994). Over 30 years later a growth factor activity that stimulated the growth of a fibroblast cell line was identified in partially purified extracts from bovine pituitary. It was called "fibroblast growth factor", simply due to the assay used to measure activity (Rudland et al. 1974). Though an unsatisfactory name, because FGFs do far more than stimulate fibroblast growth and in a considerable number of instances they do not even possess this activity, the label has stuck (see (Burgess \& Maciag 1989) for other early names and a brief overview of the discovery of FGF-1 and FGF-2). A great deal of the early work on FGFs, including that of Trowell and Wilmer (Trowell \& Willmer 1939), was from a cancer perspective, driven by the idea that uncontrolled proliferation is a hallmark of cancers and so growth factors must have a key role to play. Moreover, the ambition to cure cancers provided funding for this and much subsequent work on FGFs and other growth factors. This was not misplaced, since the analysis of experimental tumours and of activities capable of transforming cells in vitro enabled the discovery of some,

91 but not all of FGFs -3 to -9 (summarised in (Burgess \& Maciag 1989; Fernig \& Gallagher 1994))

92 and there are a number of successful FGF receptor (FGFR) inhibitors in oncology (Carter et al. 93 2015; Turner \& Grose 2010). 
94 The interaction with heparin was key to the successful purification of FGF-1 and -2 (Maciag et al. 95 1984; Shing et al. 1984), and was translated into work on the interaction of these FGFs with the 96 glycosaminoglycan heparan sulfate (HS) in the pericellular and extracellular matrix, e.g., 97 (Vlodavsky et al. 1987). The FGF receptor (FGFR) tyrosine kinases were then identified and 98 soon after, the dependence of the growth factor activity of FGFs on heparan sulfate (Rapraeger et 99 al. 1991; Yayon et al. 1991) was discovered. This provided a framework within which to 100 understand function, heparan sulfate controlled the transport of FGFs between cells and was a 101 part of a dual receptor (heparan sulfate + FGFR) signalling system. Subsequently, some FGFs 102 were found to not bind heparan sulfate, but to interact with a protein co-receptor, Klotho; these 103 FGFs do not elicit a growth factor response, but instead are endocrine hormones (Belov 2013; 104 Kuro-o et al. 1997; Martin 2012). A further set of FGF proteins, the FGF homology factors or 105 FHFs, are wholly intracellular and do not interact with any of the extracellular receptors and 106 partners of FGFs. As such they are not directly part of the FGF cell communication system and

107 lie outside the scope of this review (for review see (Goldfarb 2005))

\section{The FGF communication system: molecules and structure}

110 The core of the FGF communication system comprises a family of ligands, the FGFs, a family of 111 cell surface signal transducing receptors, the FGFRs, and two distinct co-receptors, the Klothos 112 and the glycosaminoglycan heparan sulfate, which is the physiologically relevant 113 polysaccharide; heparin is often used as its experimental proxy, but has important structural 114 differences.

\section{The FGF ligand family}

117 Phylogenetic analysis of human protein sequences indicates that there are seven FGF 118 subfamilies: FGF1 and FGF2 (FGF1 subfamily); FGF4, FGF5 and FGF6 (FGF4 subfamily); 119 FGF3, FGF7, FGF10 and FGF22 (FGF7 subfamily); FGF8, FGF17 and FGF18 (FGF8 120 subfamily); FGF9, FGF16 and FGF20 (FGF9 subfamily); FGF11, FGF12, FGF13 and FGF14 121 (FGF11 subfamily); FGF19, FGF21, and FGF23 (FGF19 subfamily) (Fig. 1). The members of

122 FGF8, FGF9, FGF11 and FGF19 subfamilies are consistent between the phylogenetic analysis 123 and the gene location analysis. However, FGF5 and FGF3 are indicated to be members of FGF4 124 and FGF7 subfamilies by the analysis of gene location on chromosomes (Horton et al. 2003; Itoh 
125 2007; Itoh \& Ornitz 2008; Itoh \& Ornitz 2011). The phylogenetic relationship based on sequence

126 maps to functional similarities of the FGFs (Ornitz et al. 1996; Xu et al. 2013; Zhang et al. 2006)

127 and it is in this context that FGF subfamilies will be discussed here.

128

129 FGF ligand structure

130 The molecular weight of FGFs range from 17 to $34 \mathrm{kDa}$ in vertebrates, whereas it reaches to 84

$131 \mathrm{kDa}$ in Drosophila. All FGFs share an internal core of similarity with 28 highly conserved, and

132 six invariant amino acid residues (Ornitz 2000). X-ray crystallography of FGFs shows that the

133 FGF family possesses a similar folding pattern to the interleukins IL-1 $\beta$ and IL-1 $\alpha$ (Zhu et al.

134 1991), a $\beta$ trefoil structure, formed by three sets (Fig. 2a) of four $\beta$ strands connected by loops

135 (Fig. 2b) (Zhang et al. 1991). A variety of studies have demonstrated that the primary heparan

136 sulfate binding site of FGF2 is formed by the strand $\beta 1 / \beta 2$ loop, strands $\beta 10$ / $\beta 11$ loop, strand

$137 \beta 11$ and strands $\beta 11 / \beta 12$ loop (Fig. 3b) (Baird et al. 1988; Faham et al. 1996; Li et al. 1994;

138 Thompson et al. 1994; Zhang et al. 1991). The receptor binding site involves the strands $\beta 8$ - $\beta 9$

139 loop and is distinct from the primary heparan sulfate binding site (Figs 3a, b). This indicates that

140 the binding to receptor and to heparan sulfate are physically separated (Itoh \& Ornitz 2004;

141 Ornitz \& Itoh 2001; Zhang et al. 1991). Secondary heparan sulfate binding sites are also present

142 in many FGFs and their position on the surface of the ligands may follow their sequence

143 phylogenetic relationship (Ori et al. 2009; Xu et al. 2012) (Figs 3b, c).

144

145 Receptors: Heparan sulfate and FGFR

146 Heparan sulfate:- Proteoglycans are O-glycosylated proteins, such as perlecan, glypicans and 147 syndecans (Taylor \& Gallo 2006; Yung \& Chan 2007). The heparan sulfate chains bind and 148 regulate the function of over 435 extracellular proteins, including the paracrine FGFs (Gallagher 149 2015; Ori et al. 2008; Ori et al. 2011; Xu \& Esko 2014). The proteoglycan core proteins are 150 synthesized on the rough endoplasmic reticulum and then transported to the Golgi apparatus 151 where the glycosaminoglycan chains are synthesised (Yanagishita \& Hascall 1992). The 152 glycosaminoglycan chains are linear polysaccharides mainly consisting of repeating disaccharide 153 units (Fig. 4a) (Gallagher 2015; Ori et al. 2008; Taylor \& Gallo 2006; Xu \& Esko 2014). The 154 members of the glycosaminoglycan family are heparan sulfate, chondroitin sulfate (CS), 155 dermatan sulfate (DS), hyaluronan (HA) and keratan sulfate (KS) (Delehedde et al. 2001). 
156 Heparan sulfate is made of repeating disaccharide units of glucuronic acid linked to N157 acetylglucosamine (Fig. 4a). In the Golgi apparatus, the synthesis of heparan sulfate chains is 158 started by the assembly of a tetrasaccharide linkage onto a serine residue of the core protein by 159 four enzymes acting sequentially (Xyl transferase, Gal transferase I and II and GalA transferase); 160 the repeat disaccharide units, [4-GlcA $\beta 1-4$ GlcNac $\beta 1-]_{\mathrm{n}}$ (where $\mathrm{n} \sim 25$ to 100) are then added by 161 the copolymerases EXT1 and EXT2 (Dreyfuss et al. 2009; Lin 2004; Tumova et al. 2000). After 162 the synthesis of the chain, clusters of $\mathrm{N}$-acetyl glucosamine are removed and N-sulfate groups 163 are added by the dual activity N-deacetylase-N-sulfotransferases (NDSTs) (Dreyfuss et al. 2009; 164 Lin 2004; Tumova et al. 2000). The subsequent modifications are on N-sulfated glucosamine 165 containing disaccharides or their neighbours: an epimerase converts glucuronic acid to iduronic 166 acid, which may then be 2-O sulfated and the glucosamine may be 6-O and 3-O sulfated 167 (Dreyfuss et al. 2009; Lin 2004; Tumova et al. 2000).

Since NDSTs selectively act on blocks of disaccharides, the modified heparan sulfate has a domain structure of NA, NAS domain and S domains (Fig. 4b) (Connell \& Lortat-Jacob 2013; Dreyfuss et al. 2009; Gallagher 2015; Murphy et al. 2004; Ori et al. 2008). Differences in sulfation level of the NAS and NS domains provide the means for heparan sulfate to bind with varying degrees of selectivity to over 435 proteins (Ori et al. 2008; Xu \& Esko 2014), including FGFs binding S-domains and antithrombin III binding transition domains (Turnbull et al. 2001; $\mathrm{Xu} \&$ Esko 2014). Since the modification reactions by the sulfotransferases do not go to completion, the length and level of sulfation of heparan sulfate chains are also variable in different cells and extracellular matrices (Dreyfuss et al. 2009; Kirkpatrick \& Selleck 2007; Ori et al. 2008; Xu \& Esko 2014).

179

FGFR

181 FGFRs, spanning the membrane, are the key to transferring induced signals into the cell, which 182 direct the target cell activities, such as cell proliferation, differentiation and migration (Beenken 183 \& Mohammadi 2009; Ornitz 2000; Turner \& Grose 2010). Five different FGFRs (FGFR1-4 and 184 FGFRL1) and many of their alternative spliced isoforms have been found to bind with FGFs and 185 activate a large number of signalling pathways (Dorey \& Amaya 2010; Itoh \& Ornitz 2011; 186 Turner \& Grose 2010; Wiedemann \& Trueb 2000). FGFR1-4 possess three extracellular 
187 immunoglobulin-like loops, I, II and III (often termed D1, D2 and D3), a transmembrane linker 188 and a cytoplasmic kinase domain (Beenken \& Mohammadi 2009; Dorey \& Amaya 2010; Goetz 189 \& Mohammadi 2013; Turner \& Grose 2010). FGFRL1 differs in that its intracellular domain 190 lacks a tyrosine kinase (Kim et al. 2001; Sleeman et al. 2001; Wiedemann \& Trueb 2000). Half 191 of D3 is encoded in FGFR1, FGFR2 and FGFR3 by alternative exons. This gives rise to the ' $b$ ' 192 and ' $c$ ' isoforms of the transmembrane receptor, which impart additional ligand selectivity

193 (Ornitz et al. 1996; Zhang et al. 2006). In addition, the tyrosine kinase FGFRs also bind heparan 194 sulfate (Kan et al. 1993; Powell et al. 2002), which leads to one ternary FGF-FGFR-heparan 195 sulfate signalling structure (Schlessinger et al. 2000).

196 The FGFRs have varying degrees of selectivity for different FGFs, and the selectivity is most 197 conserved between FGFs in the same subfamily (Ornitz et al. 1996; Xu et al. 2013; Zhang et al. 198 2006). FGF1 was recognised as a universal ligand for all the FGFRs, while FGF2 and members 199 of the FGF4 subfamily prefer to interact with FGFR 1c (Zhang et al. 2006). For the 'c' isoform, 200 the preference is FGFR 1c > FGFR 2c and FGFR 3c, though the FGF4 subfamily ligands are 201 clearly distinguished from the FGF1 subfamily in terms of their selectivity for FGFR 1b, which 202 they do not bind, in contrast to FGF1 and FGF2 (Ornitz et al. 1996; Zhang et al. 2006). Members 203 of the FGF8 and FGF9 subfamilies preferentially bind to FGFR 3c (FGFR 3c > FGFR 2c and 1c), 204 while members of FGF7 subfamily mainly bind FGFR 2b and 1b (Ornitz et al. 1996; Zhang et al. 205 2006).

206

207 Klotho co-receptors

208 Klotho co-receptors (alpha and beta-Klotho/KLB) are type 1 transmembrane proteins that define 209 tissue specific activities of circulating endocrine FGFs (for reviews see (Belov 2013; Kuro-o 210 2012; Martin 2012)). $\alpha$ Klotho was originally identified as an aging suppressor gene (Kuro-o et al. 211 1997). Findings that mice with disrupted $\alpha$ Klotho expression displayed identical phenotypes to 212 mice deficient in FGF23, including shortened life span, growth retardation, muscle atrophy, 213 vascular calcification in the kidneys and disrupted serum phosphate balance, led to the discovery

214 of aKlotho as an obligatory co-receptor for FGF23 to bind and activate FGFR in the kidney 215 (Kurosu et al. 2006; Urakawa et al. 2006). Bone derived FGF23 acts in the aKlotho expressing 216 kidney to regulate vitamin D and phosphate homeostasis. Beta-Klotho (KLB) was identified by 217 its sequence homology to $\alpha$ Klotho (Ito et al. 2000), and later identified as a co-receptor to allow 
218 FGF19 and -21 to bind and signal via their canonical FGFRs in bile acid, glucose and lipid 219 metabolism, respectively (Kharitonenkov et al. 2008; Kurosu et al. 2007; Lin 2007; Wu et al. 220 2007). The extracellular domains of Klotho co-receptors are composed of two KL domains with 221 sequence homology to beta-glucosidases (Ito et al. 2000; Kuro-o et al. 1997). $\alpha$ Klotho also exists 222 in a secreted form, either via alternative splicing or via shedding of the extracellular domain by 223 matrix metalloproteases. The secreted form of Klotho has been shown to modulate glycans on 224 Transient Receptor Potential calcium channels TRPV5 and TRPV6 (Chang et al. 2005) and renal 225 outer medullary potassium channels (ROMK1) (Cha et al. 2009) in vitro, increasing their cell226 surface retention.

227

\section{Assembly of signalling complexes}

229 The binding of the FGF ligand to its receptor with/without heparan sulfate (co-receptor) causes 230 the FGFR to dimerise. This in return enables phosphorylation of tyrosine residues in the kinase 231 activation loop and then of tyrosines that are docking sites for signalling proteins (Goetz \& 232 Mohammadi 2013). The latter activate most intracellular signalling pathways, e.g. RAS-RAF233 MAPK and PI3K-AKT, which regulate cell fate and specific cell activities (Dorey \& Amaya 234 2010; Turner \& Grose 2010). Previous studies suggest heparan sulfate (or its experimental proxy 235 heparin) is required for many, but not all signalling (Izvolsky et al. 2003). FGF signalling can be 236 negatively regulated by internalisation and degradation, as well as by transmembrane regulators, 237 such as FGFRL1, and intracellular ones, e. g. Sprouty and Spred (Casci et al. 1999; Hacohen et 238 al. 1998) and MAPK phosphatase 3 (Turner \& Grose 2010). Since there is a great diversity of 239 FGF ligands, FGFR isoforms and heparan sulfate structure and feedback loops, the understanding of FGF signalling is still far from complete (Dorey \& Amaya 2010).

\section{Alternative partners}

243 FGFs and FGFRs interact directly with a large number of other partners, both extracellularly and,

244 following the internalisation of ligand-receptor complexes, intracellularly. In some instances, e.g., 245 FGF-2 binding integrins (Rusnati et al. 1997), these may be additional to the core complex of 246 FGF, FGFR and heparan sulfate, but in other cases, e.g., cadherins, these are orthogonal partners 247 of one component of the core FGF communication system, the FGFR (Doherty \& Walsh 1996). 248 A partial list of the alternative extracellular partners has been reviewed (Polanska et al. 2009b). 
249 The intracellular partners and functions of FGF receptor-ligand complex components 250 translocated to the nucleocytoplasmic space have also been recently reviewed (Coleman et al. 251 2014).

252

\section{Diversification and switching of function: hints from $C$. elegans}

254 The functions of FGFs in mammals are very diverse, which reflects the expansion at the 255 molecular level of the FGF communication system that accompanied the evolution of more 256 complex animal body plans and physiology. In contrast $C$. elegans possesses one of the simplest FGF communication systems, comprising two ligands, EGL-17 (Burdine et al. 1997) and LET756 (Roubin et al. 1999), a single FGFR, EGL-15 (DeVore et al. 1995), and two orthologues of Klotho, KLO-1 and KLO-2 (Polanska et al. 2011). The EGL-15 receptor is alternatively spliced into an " $\mathrm{A}$ " and a "B" isoform, resulting in structural differences in the extracellular domain of the receptor between immunoglobulin domains I and II (Goodman et al. 2003). Work in $C$. elegans provides an insight into the relation between the paracrine and endocrine activities of FGFs and how heparan sulfate binding of FGFs may have changed during the expansion of the family. This in turn provides one line of evidence to support the argument that we can manipulate the FGF communication system therapeutically for patient benefit in repair and metabolic scenarios, without undue risk of tumourigenesis.

267 The major functions of EGL-15 are paracrine in the cell migration of sex myoblasts (DeVore et al. 1995), neural development (Bulow et al. 2004; Fleming et al. 2005), and an early essential function (DeVore et al. 1995) associated with physiological homeostasis (Huang \& Stern 2004; Polanska et al. 2009a; Polanska et al. 2011). EGL-17/FGF acts as a chemoattractant to guide sex myoblasts (Burdine et al. 1998), whereas LET-756/FGF is required for the essential function of EGL-15, as animals lacking LET-756 arrest at early larval stage (Roubin et al. 1999). In mammals, the "IIIb" and "IIIc" isoforms of FGFRs enable ligand selectivity. In C. elegans this

274 ligand to receptor pairing is determined in part by tissue specific expression of the ligand and the "A" and "B" receptor isoforms (Goodman et al. 2003; Lo et al. 2008). egl-15(5B) is predominantly expressed in the hypodermis (Lo et al. 2008), where it mediates fluid homeostasis

277 (Huang \& Stern 2004), whereas egl-15(5A) isoform is expressed in the M lineage, which gives 278 rise to the sex myoblasts. Heterologous expression of egl-17, driven by the let-756 promoter, can 279 stimulate EGL-15(5B) and partially rescue the larval arrest phenotype of mutants lacking LET- 
280756 , and expression of let-756 driven by egl-17 promoter can partially rescue sex myoblast 281 migration in EGL-15-deficient worms (Goodman et al. 2003). However, although expression of 282 either isoform of egl-15 in the hypodermis can mediate the fluid homeostasis phenotype, only 283 EGL-15(5A) isoform can mediate sex myoblast chemoattraction (Lo et al. 2008). Thus, the 284 functional specificity of EGL-15 is determined by the extracellular receptor isoform and the 285 availability of the ligand. That there are no multicellular organisms possessing just a single FGF 286 ligand and one FGFR isoform may reflect the importance of selective communication between 287 tissue compartments and of the ability of cells to switch the ligand channel they are tuned to 288 during development, without changing the receiver (the receptor kinase and downstream 289 signalling).

290 The role of EGL-15 in the regulation of C. elegans fluid homeostasis was first discovered in 291 mutants of a phosphatase, which acts downstream of EGL-15 (Kokel et al. 1998). This 292 phosphatase, CLR-1, acts as a negative regulator of EGL-15, and its absence leads to excess 293 EGL-15 activity and accumulation of fluid within the C. elegans pseudocoelom and a clear (clr) 294 phenotype. Excess EGL-15 activity and clear phenotype can also be achieved by mutation of $\mathrm{N}$ 295 glycosylation sites in the extracellular domain of the EGL-15 receptor (Polanska et al. 2009a), as $296 \mathrm{~N}$-glycans act as a brake on receptor activation (Duchesne et al. 2006). Under laboratory 297 conditions $C$. elegans must actively excrete fluid. The major organs responsible for fluid balance 298 are the hypodermis, which expresses egl-15(5B) and klo-2 (Polanska et al. 2011) and the 299 excretory canal, which is equivalent to the mammalian kidney and expresses klo- 1 (Polanska et 300 al. 2011). Complete loss of function of EGL-15 or LET-756 leads to loss of klo- 1 expression and 301 lack of functional excretory canals (Polanska et al. 2011), a likely explanation of the early larval 302 lethality of the mutants defective of LET-756/EGL-15 signalling.

303 Thus, in C. elegans the same FGFs act as growth factors, morphogens and hormones, whereas in 304 mammals different FGFs perform the local and systemic functions. EGL-15 associates with 305 Klotho co-receptors to mediate the fluid homeostasis function (Polanska et al. 2011), which is 306 entirely analogous to the mode of action of endocrine FGFs in mammals.. Although there is 307 currently no genetic evidence to suggest that, as in mammals, the assembly of a signalling 308 complex of the C. elegans FGF ligands with EGL-15 and subsequent receptor activation would 309 depend on the heparan sulfate co-receptor in vivo, biochemical evidence shows that EGL310 15/FGFR binds to heparin, a proxy for heparan sulfate (Polanska et al. 2011), whereas sequence 
311 alignment of EGF-17 and LET-756 to mammalian FGFs indicates that they possess heparan

312 sulfate binding sites (Xu et al. 2012). Importantly, binding to heparan sulfate would not preclude

313 a hormone homeostatic activity of $C$. elegans FGFs, since the range of the FGF would be

314 significant compared to the animal's body size; C. elegans is small, (adult hermaphrodites $\sim 1$

$315 \mathrm{~mm}$ ). Thus, a reasonable hypothesis is that the communication system used in development,

316 LET-756 and EGL-15, is then co-opted into endocrine homeostasis. As animals grew larger, this

317 would no longer be possible. Diversification of the FGF family and weakening of heparan

318 sulfate binding would then allow both the growth factor/morphogen activity, which is local due

319 to heparan sulfate binding and the systemic hormonal activity to be retained. In support of this

320 idea is the demonstration that a human FGF-1 with its primary heparan sulfate binding site

321 mutated is reprogrammed from a growth factor to a FGF-21 like hormone, controlling

322 metabolism (Suh et al. 2014). A corollary is that the interaction of paracrine FGF ligands with

323 heparan sulfate is one key to understanding their function, their roles in disease and hence their

324 therapeutic potential.

325

326 The aspects of FGF activities linked to cancers

327 As noted above, a great deal of the early work on FGFs was from a cancer perspective, though

328 there was also a considerable effort directed at regeneration of damaged tissues. While there is a

329 bias in the scientific literature against reporting negative results, there are some reports that

330 showed in animal models and in clinical samples that there was not a simple relationship

331 between FGF ligand expression and tumour formation and progression. Thus, when FGF-2

332 mRNA levels were analysed in a cohort of breast cancer patients, elevated expression of FGF-2

333 mRNA correlated with a good prognostic outcome, the opposite of the result expected from the

334 naïve perspective that "FGF2 = uncontrolled growth + angiogenesis = cancer" (Anandappa et al.

335 1994). Similarly, in a syngeneic rat model of breast cancer, overexpression of FGF2 failed to

336 produce any metastases (Davies et al. 1996). Given the difficulty in publishing negative results,

337 there is likely a very large body of work that demonstrates the absence of a direct association

338 between the expression of FGF ligands and cancer.

339 One reason is that, at least for FGF-1 and FGF-2, the ligand is often not limiting. That is, there is

340 a lot of ligand stored on heparan sulfate in tissues, which is then accessed during repair. The

341 discovery of the storage of FGF2 on heparan sulfate of extracellular matrix (Vlodavsky et al. 
342 1987) was followed by the realisation that stored FGF2 could elicit a response at least in cultured

343 cells (Presta et al. 1989) by diffusion within matrix (Duchesne et al. 2012). The expression of

344 other FGF ligands is, in contrast, often induced. However, like FGF1 and FGF2, their activity is

345 restricted, again through binding to heparan sulfate and due to their selectivity for FGFRs. An

346 important facet of development and endogenous tissue repair is the mobilisation of FGF ligands

347 by heparanase, a beta glucuronidase, which cleaves heparan sulfate in NA and NAS domains,

348 liberating growth factor bound to an S domain (Arvatz et al. 2011; Barash et al. 2010; Kato et al.

349 1998; Patel et al. 2010; Ramani et al. 2013). This plays a key role in many cancers (Arvatz et al.

350 2011; Barash et al. 2010; Ramani et al. 2013). Therefore, the mechanistic link between the FGF

351 communication system and cancers is on the side of the mobilisation of FGFs from such stores

352 (particularly by heparanase, though proteases are likely to also have a role) and of increases in 353 the activity of FGFRs (Carter et al. 2015; Turner \& Grose 2010). Thus, in contrast to their

354 ligands, the FGFRs are established drivers of tumour progression. This arises from: activating 355 mutations; isoform switching, e.g., between the classic epithelial, FGFR2-IIIb isoform that binds 356 FGF-7 family members and FGFR2-IIIc isoform, that binds epithelial synthesized and 357 mesenchymally stored FGFs, including FGF-2 (Carter et al. 2015; Turner \& Grose 2010).

\section{FGFs as repair factors}

360 The use of FGFs to repair damaged tissue is a long-standing research area, however, until 361 recently in the West it was entirely confined to model systems. In Japan, alongside the cancer research track, a repair track leading to clinical applications was developed. In contrast, in China FGF research was from the late 1980s spearheaded by the drive to develop a biotechnology industry. This resulted in successful engineered production of FGF1 and FGF2, e.g., (Wu et al. 2005; Wu et al. 2004; Yao et al. 2006; Zhao et al. 2004) and a substantial effort in experimental medicine, including pharmacokinetic and toxicity studies, e.g., (Li et al. 2002; Xu et al. 2003) to develop clinical applications. In much of this work the original nomenclature, aFGF and bFGF is used for FGF1 and FGF2, respectively; in the following summary of some of the clinical studies, the currently accepted numerical nomenclature is employed. A major clinical focus in China has been the use of FGF2 as a repair/regeneration factor in conditions as diverse as burns, chronic wounds, oral ulcers, vascular ulcers, diabetic ulcers, pressure ulcers and surgical incisions. As the Chinese studies are not generally accessible, we have summarised a number of these below, 
373 alongside other work on similar conditions from Japanese research groups and the few Western

374 clinical trials. The very extensive preclinical literature is not covered.

375

376 Therapeutic applications of FGF2

377 FGFs have been investigated as therapeutic agents in a number of diseases, with varying success.

378 We outline some of the studies (Table), ranging from case series and observational studies

379 carried out prospectively (before treatment has been initiated) or retrospectively (after treatment

380 has been completed) or a combination of retrospective and prospective approaches to well-

381 designed randomised controlled studies carried out prospectively. The quality of the studies is

382 variable and with details of the FGFs used not available in all instances (Table).

383

384 Burns

385 Liu et al. (Liu et al. 2005) investigated the use of FGF2 in the treatment of burns and chronic

386 wounds. Patients were divided into a burn wound group ( $\mathrm{n}=62)$, a donor site wound group

387 ( $\mathrm{n}=36)$ and a chronic wound group $(\mathrm{n}=65)$. The burn wounds included superficial partial

388 thickness burns and deep partial thickness burns; chronic wounds included wounds that did not

389 heal following routine treatment for 4 weeks, residual granulation wounds, pressure ulcers,

390 sinuses, and diabetic ulcers. The burn wound group was treated with FGF2 in addition to the

391 standard treatment. Self-control randomization was applied to the burn wound group and donor

392 site wound group, with comparisons of the same subject before and after treatment. The control

393 group was treated with equal amounts of saline in addition to the standard treatment. The results

394 showed that FGF2 significantly shortened the time to complete wound healing in the three

395 wound groups compared to the control group.

396 Guo et al. (Guo 2006) randomly assigned 80 cases of deep partial thickness burn wounds to a

397 treatment group and a control group. In the treatment group, a gauze pad impregnated with FGF2

398 solution was applied to the debrided wound, which was then covered with another gauze pad

399 containing $1 \%(\mathrm{w} / \mathrm{w})$ silver sulfadiazine. Apart from substituting normal saline for FGF2, the

400 control group was subjected to the same treatment as the FGF2 group. The results showed that

401 the average healing time for superficial partial thickness burn wounds in the FGF2-treated group

402 was significantly shorter as compared to the control group $(9.51 \pm 1.86$ days $v s .12 .43 \pm 2.03$

403 days, $p<0.05$ ). Similarly, the healing time in the deep partial thickness burn wounds in the FGF2 
404 treatment group was significantly shorter than the control group (18.36 44.87 days vs. $22.35 \pm$ 4055.60 days, $p<0.01)$.

406 FGF2 has also been shown to accelerate healing and improves scar quality in second-degree

407 burns (Akita et al. 2008). Since the speed of wound healing is an important factor influencing the 408 outcome of treatment, as well as a crucial step in burn wound treatment, and the quality of 409 wound healing has a direct bearing on the quality of life of patients, FGF2 clearly has clinical 410 efficacy in a variety of burn settings.

411

412 Surgical wounds

413 Surgical incisions:- Surgical incisions leave scars as part of the normal healing process. These 414 scars vary from being narrow, wide, atrophied or hypertrophic and sometimes cause medical 415 problems, or social ones, because of their cosmetic appearance (Rockwell et al. 1989). A study 416 by Ono et al. (Ono et al. 2007) examined the effect of local administration of FGF2 on sutured 417 wounds. FGF2 was injected into the dermis of the wound margins using a needle immediately 418 after the skin was sutured following an operation. None of the patients treated with FGF2 had 419 hypertrophic scars compared to the control group and scarring was significantly lower in the 420 groups treated with FGF2, as compared to the control group.

421

422 Skin graft wounds:- Healing of the donor site wounds, created after skin graft harvesting, 423 involves the regeneration of epithelial cells in the residual skin appendages (Metcalfe \& 424 Ferguson 2007). Early healing of donor site wounds helps to reduce trauma, thereby facilitating 425 the treatment of the primary disease.

$426 \mathrm{Xu}$ et al. (Xu et al. 2000) conducted a clinical study to examine the efficacy of topical 427 application of FGF2 on 48 donor site wounds in 34 patients, which were created by harvesting 428 intermediate split thickness skin grafts. The wounds before treatment served as self-controls. 429 Following the harvesting of the skin grafts, the wound surface was evenly coated with FGF2 430 using a cotton swab, covered with vaseline gauze, and dressed. The control wounds were 431 smeared only with the vehicle without FGF2, the rest of the topical treatment procedures being 432 identical as the treatment group. The results showed healing time in wounds treated with FGF2 433 was 2.8 days shorter compared to control wounds $(p<0.01)$. Moreover, FGF2-treated wounds 
434 appeared flatter, smoother and firmer and were difficult to tear off, as compared to the control 435 wounds. The use of FGF2 yielded no adverse reactions.

436

437 Full thickness skin grafts in avulsion injuries:- Matsumine et al. (Matsumine 2015) described the 438 topical use of FGF2 in the treatment of avulsion wounds (as a result of skin and/or underlying 439 tissue torn away due to trauma) with full thickness grafts using the avulsed skin. The 440 contaminated subcutaneous fat tissue on the inside of skin was excised and the avulsed skin was 441 processed into a full-thickness skin graft. Drainage holes (5-10 $\mathrm{mm}$ in diameter) were made on 442 the graft to prevent seroma and haematoma formation. FGF2 was sprayed onto the graft bed, 443 followed by application of the graft. Skin grafts that did not take were scraped away, preserving 444 the revascularized viable dermis where possible. FGF2 was then sprayed again onto this surface 445 to promote epithelialization (proliferation of epithelial cells to cover the wound). Wound closure 446 was achieved in all cases with conservative therapy. This procedure promoted wound healing 447 with the formation of good-quality, flexible scars and prevented postoperative ulcer formation 448 and scar contracture.

449

450

Cosmetic surgical incisions:- Wound healing quality is important in the success of cosmetic 451 surgery. Lu et al. (Lu et al. 2006) examined the effects of FGF2 on wound repair in 60 female patients who underwent cosmetic surgery. All surgical incisions were clean cuts, and self453 controls (another incisional wound on the same patient) were used. In the treatment group FGF2 was applied once daily until removal of stitches, starting with the first postoperative day. Wounds due to laser resurfacing were smeared with FGF2 twice daily until natural decrustation occurred. The control group was subjected to conventional dressing change until removal of stitches. The results showed that in the FGF2 group whose wounds resulted from laser resurfacing, the average decrustation time was significantly shorter than in the control group $(6.2$ days vs. 8.1 days, $\mathrm{p}<0.05)$. The FGF2-treated groups showed good healing. In addition, exudate and swelling post surgery were milder in the FGF2 groups than in the control group. There were no adverse reactions in the FGF2 groups. Quality of wound healing was superior and the healing

462 time was shorter in the FGF2 groups as compared to the control group, indicating that FGF2 has 463 a favourable effect on cosmetic surgical incision healing. 
465 Obstetric wounds:- Dehiscence of caesarean section incisions may occur in the form of a 466 superficial dehiscence, in which the skin and subcutaneous fat layer break open, most often due 467 to fat liquefaction caused by subcutaneous fat hypertrophy in pregnant women. In addition, a 468 long trial of labour, excessive vaginal examinations, vaginitis, and intrauterine infections may 469 potentially lead to an increase in infected incisions. Anaemia, hypoproteinemia, malnutrition, 470 and diabetes in the perinatal period can result in poor healing capacities of local tissues. These 471 factors can adversely affect wound healing extending hospital stay, and increasing costs.

472 Chen et al. (Chen \& He 2004) randomly assigned 60 patients with wound dehiscence following a 473 caesarian section to two groups: an observation group and a control group. After debridement of 474 the wounds, FGF2 was sprayed on the wounds and they were sutured the next day. Wound 475 dressings were changed regularly. The control group was treated similarly, but without the use of 476 FGF2 spray. Healing time was significantly shorter in patients with dehiscence measuring $5 \mathrm{~cm}$ 477 in size or below treated with FGF2 compared to the control group $(6.8 \pm 1.5$ days vs.11.2 \pm $4781.2, p<0.01)$. In contrast, in patients with dehiscence measuring $5 \mathrm{~cm}$ and above secondary 479 suturing was undertaken. In this instance there was no significant difference in the FGF2 treated 480 group compared to their respective control group ( $7.6 \pm 1.0$ days $v s$. to $7.4+/-0.8, p>0.05)$; it is 481 likely that this control group's shortened healing time, compared to the control group with 482 dehiscence measuring $5 \mathrm{~cm}$ or less, was due to secondary suturing.

483

484 Orthopaedic trauma wounds:- FGF signalling plays an important role in skeletal development 485 (Su et al. 2008). Tissue necrosis and infection of fresh skin defect wounds, grafted flaps, and skin 486 grafts occurs following orthopaedic trauma surgery. In order to shorten the healing time and 487 reduce the rate of skin re-grafting, FGF2 has been directly applied to fresh and debrided necrotic 488 wounds.

489 Kawaguchi et al. (Kawaguchi et al. 2010) conducted a randomised, placebo-controlled trial, 490 investigating the direct application of FGF2 in a gelatin hydrogel on traumatic tibial fractures. A 491 single injection of gelation containing placebo or low dose FGF (0.8 mg) or high dose FGF (2.4 $492 \mathrm{mg}$ ) was administered into the fracture gap at the end of intramedullary nailing surgery. 493 Radiographic bone union was significantly higher in the FGF2 treated groups, with no significant 494 difference between the two FGF2 dosage groups. 
495 Zang et al. (Zang et al. 2005) investigated the use of a FGF2 biological protein sponge for 496 traumatic ulcers. A sterile FGF2 biological protein sponge was applied to traumatic skin ulcers in 49720 patients. The results showed that the wound-healing rate within 3 weeks was 95\% in the FGF 498 group and 55\% in the control group, and that the rate of skin re-grafting in the FGF2 group was 499 significantly lower than that in the control group. Wound secretions and peri-wound 500 inflammation were markedly less severe in the FGF2 group as compared to the control group. No 501 obvious adverse reactions were reported in either group. These data indicate that FGF2 502 biological protein sponges may promote the healing of traumatic ulcers and shorten healing time. 503

504 Oral Diseases:- Oral ulcers are a common disease of the oral mucosa and tend to recur.

505 Pathologically, ulcers of oral mucosa are mainly characterized by dissolution, rupture, and 506 shedding of local oral mucosal epithelium to form non-specific ulcers.

507 A study by Jiang et al. (Jiang et al. 2013) investigated the use of topical application of 508 diosmectite (DS; an insoluble silicate) and FGF2 paste in the treatment of minor recurrent 509 aphthous stomatitis (repeated formation of benign, non-infectious ulcers in the mouth). Four 510 pastes, containing FGF2 and DS, DS alone, FGF2 alone, and vehicle only, were used in 129 511 participants. DS-FGF2 significantly lowered ulcer pain scores ( $p<0.05$ for days 3, 4, 5, and 6) 512 as compared to the other pastes. Ulcer size was significantly reduced ( $p<0.05$ for days 2,4 , and 513 6) in this group. No obvious adverse drug effects were observed.

514 Kitamura et al. (Kitamura et al. 2011) conducted a multicentre, randomised, double blind, 515 placebo-controlled trial, in accordance with Good Clinical Practice guidelines, to clarify the 516 efficacy and safety of FGF2 use in periodontal regeneration. The percentage of bone fill was 517 significantly higher in the FGF2 treatment group as compared to the 'vehicle alone' group at 36 518 weeks. Also, there were no serious adverse effects in the treatment group.

519 Radiotherapy is commonly used to treat head and neck cancer. However, when the radiation dose 520 rises to about $20 \mathrm{~Gy}-30 \mathrm{~Gy}$, acute inflammation of the oral mucosa usually occurs, the 521 symptoms of which include, among other things, oropharyngeal pain, and oral ulcers associated 522 with oedema or pseudomembrane formation. Food intake is affected as a result. Moreover, the 523 severity of the symptoms increases with the radiation dose. Patients who experience serious 524 symptoms have to suspend the treatment, and the final efficacy of the treatment is thus impaired 525 (Vera-Llonch et al. 2006; Worthington et al. 2011). 
526 Myeloablative allogeneic haemopoietic stem cell transplantation is an established treatment for

527 haematologic malignancies and oral mucositis is a known complication arising from high dose 528 chemotherapy and radiation therapy. Goldberg et al. (Goldberg et al. 2013) performed a 529 retrospective study investigating the use of peritransplant Palifermin (recombinant FGF7) and 530 found that it significantly reduced the number of days of total parenteral nutrition, patient531 controlled analgesia and length of hospital stay in patients receiving total body irradiation as 532 compared to those receiving chemotherapy based transplantation.

533 Ren et al. (Ren \& Shun 2002) conducted a double-blind study, in which 121 patients with mild 534 aphthous ulcers (mouth ulcers) were randomly assigned to either a FGF2 group ( $\mathrm{n}=63$ ) or a 535 control group ( $\mathrm{n}=58$ ). In the FGF2 group, FGF2 was locally sprayed onto the surface of ulcers; 536 in the control group, $0.2 \%(\mathrm{w} / \mathrm{v})$ chlorhexidine solution was sprayed on the ulcers. The results 537 showed that the effective rate at day 3 was $90.48 \%$ in the FGF2 group and $60.34 \%$ in the control 538 group $(\mathrm{p}<0.05)$. Meanwhile, the average healing time of ulcers was significantly shorter in the 539 FGF2 group than in the control group (Chi square test; $p<0.05$ ). The results show that FGF2 540 exhibits significant efficacy for mild recurrent aphthous oral ulcers.

542 Tympanic membrane perforations:- While most traumatic perforations of the tympanic 543 membrane tend to heal spontaneously, large perforations may often fail to do so. The 544 management of these is still open to debate, with a number of specialists recommending an early 545 myringoplasty to improve outcomes (Conoyer et al. 2007). Lou and Wang (Lou \& Wang 2013) 546 undertook a prospective, sequential allocation, three-armed, controlled clinical study to compare 547 perforation edge approximation vs. FGF2 application in the management of traumatic 548 perforations of the tympanic membrane. Patients were divided into 3 groups: no intervention $549(\mathrm{n}=18)$, edge approximation $(\mathrm{n}=20)$ and direct application of FGF2 $(\mathrm{n}=20)$. Otoscopy was 550 performed before and after treatment and response measurements were made, such as closure 551 rate, closure time and rate of otorrhoea. Perforation closure was significantly higher in the FGF2 552 group (100\%) as compared to the edge approximation $(60 \%)$ and control $(56 \%)$ groups $(\mathrm{p}<0.05)$. 553 Average closure time was significantly shorter in the FGF2 treatment group (12.4+/- 3.6 days), 554 as compared to the edge approximation $(46.3+/-8.7$ days $)$ and control $(48.2+/-5.3$ days $)$ groups 555 ( $\mathrm{p}<0.05)$. Lou et al. (Lou et al. 2014) showed that a lower dose $(0.1$ to $0.15 \mathrm{~mL})$ of FGF2 (21,000 $556 \mathrm{IU} / 5 \mathrm{~mL}$ ) was more effective than a higher dose $(0.25$ to $0.3 \mathrm{~mL}$ ). Hakuba et al. (Hakuba et al. 
557 2010) demonstrated that FGF2 combined with atelocollagen was an effective treatment for

558 chronic tympanic membrane perforations.

559

560 Pressure Ulcers:- Treatment of pressure ulcers is a major problem for clinical care. Pressure 561 ulcers can increase patients' suffering, extend the duration of illness, and, when serious, may 562 even prove to be life threatening due to sepsis resulted from secondary infection. Commonly 563 used treatments over the years have included innovative mattresses, ointments, creams, solutions, 564 dressings, ultrasonography, ultraviolet heat lamps, and surgery.

565 Robson et al. (Robson et al. 1992) investigated the role of FGF2 in the treatment of pressure 566 ulcers with a randomized, blinded, placebo-controlled trial, which enrolled 50 patients with 567 pressure ulcers varying in size from 10 to $200 \mathrm{~cm}^{3}$. The results showed that, compared with 568 placebo-treated patients, the number of FGF2-treated patients whose ulcers shrank by $70 \%$ increased significantly $(60 / 100$ vs. 29/100, $p=0.047)$. Histological analysis of FGF2-treated wounds showed a significant increase in the number of fibroblasts and capillaries.

571

Diabetic foot:- Diabetic foot is a serious complication of diabetes and an important cause of diabetes-related disability. When diabetic foot develops, the patient's feet are prone to injury, infection, ulcers and gangrene.

575 Uchi et al. (Uchi et al. 2009) conducted a randomized, double blind, dose-ranging, placebocontrolled trial to examine the clinical efficacy of FGF2 in the treatment of diabetic ulcers.

577

578

579

580

581

582

583

584

585

586
Patients' diabetic ulcers were randomized into a placebo group $(\mathrm{n}=51)$, a $0.001 \%(\mathrm{w} / \mathrm{v})$ FGF2 treatment group $(\mathrm{n}=49)$ and a $0.01 \%(\mathrm{w} / \mathrm{v})$ FGF2 treatment group $(\mathrm{n}=50)$, with the primary outcome being the percentage of patients showing a $75 \%$ or greater reduction in the area of ulcer. The area of ulcer decreased by $75 \%$ or more in $57.5 \%(27 / 47), 72.3 \%(34 / 47)$, and $82.2 \%$ $(37 / 45)$ in the placebo, 0.001\% (w/v) FGF2 and 0.01\% (w/v) FGF2 groups, with significant differences between the $0.01 \%(\mathrm{w} / \mathrm{v}) \mathrm{FGF} 2$ treatment and placebo groups $(p=0.025)$. Cure rates were $46.8 \%, 57.4 \%$, and $66.7 \%$ in the placebo, $0.001 \%(\mathrm{w} / \mathrm{v}) \mathrm{FGF}$ and $0.01 \%(\mathrm{w} / \mathrm{v}) \mathrm{FGF} 2$ groups. This trial showed that FGF2 accelerates healing of diabetic ulcers. 
587 Kumagai et al. (Kumagai et al. 2015) conducted a phase I-IIa trial, investigating the use of a 588 sustained release system of FGF2 using a biodegradable gelatin hydrogel in patients with critical

589 limb ischaemia. The measured transcutaneous pressure, distance walked in 6 minutes, rest pain 590 scale and cyanotic pain scale showed significant improvement at 24 weeks post-treatment as 591 compared to pre-treatment.

592

593 Other applications:- Repair of cerebrospinal fluid leakage is difficult, which is especially so 594 when a large fistula, with concomitant mucosal damage and infection, has developed from 595 repeated transsphenoidal operations. Kubo et al. (Kubo et al. 2005) reported a 27-year-old 596 woman with intractable cerebral spinal fluid rhinorrhea who had undergone repeated operations 597 for a relapsing Rathke's cleft cyst. They repaired the sellar floor defect using mucosal flaps via 598 an endonasal endoscopic approach and occluded the fistula by applying FGF2 to the area to 599 promote granulation. FGF2 was repeatedly applied endoscopically to the mucosal flaps, which 600 turned into granulation-like tissue, and complete mucosal covering was attained. This method of 601 treating the intractable fistula with mucosal flaps and FGF2 may present a new clinical 602 application of FGF2 and should be examined in a large number of patients in the future.

603 The mucosa of the vocal folds atrophies with age causing glottal insufficiency, which is difficult 604 to treat. Hirano et al. (Hirano et al. 2008) reported a case of a patient, with atrophied vocal folds, 605 who was treated with FGF2 injections into the folds under local anaesthesia. The atrophy of the 606 vocal fold improved within a week following the injection and the glottic gap disappeared. 607 Aerodynamic and acoustic parameters also showed remarkable improvement, when measured. 608 Subsequently, a trial (Hirano et al. 2012) demonstrated that this therapy might be safe and 609 effective in the treatment of age-related vocal fold atrophy.

610

611 Prospects

612 In Europe and N America, the substantial investment by cancer sources into growth factors such 613 as the FGFs has resulted in oncology directed clinical translation, in the form of FGFR inhibitors 614 (Carter et al. 2015; Turner \& Grose 2010). In contrast, the biotechnology drive in China resulted 615 in exploitation of engineered FGF ligands to repair and regenerate damaged tissue in a wide 616 range of settings, with Japan having clinical experience in both areas. We have not been able to 617 identify reports of adverse reactions to treatment with FGF ligands - these undoubtedly occur, 
618 but the frequency or their severity may be too low and confounded by the underlying medical 619 condition, such that they have not appeared in the case literature. In any event, it is clear that the 620 Chinese and Japanese experience with FGF ligands as biologics in repair and regeneration 621 clinical scenarios has been an outstanding success; FGFs in China have progressed from 622 engineered biotechnology products (Wu et al. 2005; Wu et al. 2004; Yao et al. 2006; Zhao et al. 623 2004) to the Chinese Pharmacopeia (Pharmacopeia 2015). Many of the conditions, e.g., diabetic 624 foot, make important and growing demands on healthcare systems and carry considerable 625 socioeconomic costs. Thus, Western medical practice may usefully follow where China and 626 Japan have led and explore the use of FGF ligands as repair and regeneration agents. The 627 realisation of the clinical potential of the FGF communication system outside of oncology has 628 been long overdue in the West. However, Western industry is now actively engaged in the 629 development of FGF therapeutics. This includes development of FGF21 based therapeutics for 630 metabolic syndrome (Kharitonenkov \& Shanafelt 2008; Kharitonenkov \& Shanafelt 2009; Zhang 631 \& Li 2014), of FGF7 for oral mucositis (Goldberg et al. 2013) and of FGF18 in osteoarthritis 632 (Carli et al. 2012; Mori et al. 2014), it is likely that we will see FGF biologics in clinical use in 633 the West, as well as in the East. Indeed, the use of FGF18 to treat osteoarthritis is progressing 634 through clinical trials (Lohmander et al. 2014).

635 
636

637

638

639

640

641

642

643

644

645

646

647

648

649

650

651

652

653

654

655

656

657

658

659

660

661

662

663

664

665

666

667

668

669

670

671

672

673

674

675

676

677

678

679

680

\section{References}

Akita S, Akino K, Imaizumi T, and Hirano A. 2008. Basic fibroblast growth factor accelerates and improves second-degree burn wound healing. Wound Repair and Regeneration 16:635-641.

Anandappa SY, Winstanley JHR, Leinster S, Green B, Rudland PS, and Barraclough R. 1994. Comparative expression of fibroblast growth factor mRNAs in benign and malignant breast disease. Br J Cancer 69:772-776.

Arvatz G, Shafat I, Levy-Adam F, Ilan N, and Vlodavsky I. 2011. The heparanase system and tumor metastasis: is heparanase the seed and soil? Cancer Metastasis Rev 30:253268.

Baird A, Schubert D, Ling N, and Guillemin R. 1988. Receptor- and heparin-binding domains of basic fibroblast growth factor. Proc Natl Acad Sci U S A 85:2324-2328.

Barash U, Cohen-Kaplan V, Dowek I, Sanderson RD, Ilan N, and Vlodavsky I. 2010. Proteoglycans in health and disease: new concepts for heparanase function in tumor progression and metastasis. FEBS J 277:3890-3903.

Beenken A, and Mohammadi M. 2009. The FGF family: biology, pathophysiology and therapy. Nature Reviews Drug Discovery 8:235-253.

Belov AA, Mohammadi, M. 2013. Molecular mechanisms of fibroblast growth factor signalling in physiology and pathology. Cold Spring Harb Perspect Biol 5:a015958.

Bulow HE, Boulin T, and Hobert 0. 2004. Differential functions of the C. elegans FGF receptor in axon outgrowth and maintenance of axon position. Neuron 42:367-374.

Burdine RD, Branda CS, and Stern MJ. 1998. EGL-17(FGF) expression coordinates the attraction of the migrating sex myoblasts with vulval induction in C. elegans. Development 125:1083-1093.

Burdine RD, Chen EB, Kwok SF, and Stern MJ. 1997. egl-17 encodes an invertebrate fibroblast growth factor family member required specifically for sex myoblast migration in Caenorhabditis elegans. Proc Natl Acad Sci U S A 94:2433-2437.

Burgess WH, and Maciag T. 1989. The heparin-binding (fibroblast) growth factor family of proteins. Ann Rev Biochem 58:575-606.

Carli A, Gao C, Khayyat-Kholghi M, Li A, Wang H, Ladel C, Harvey EJ, and Henderson JE. 2012. FGF18 augments osseointegration of intra-medullary implants in osteopenic FGFR3(-/-) mice. Eur Cell Mater 24:107-117.

Carter EP, Fearon AE, and Grose RP. 2015. Careless talk costs lives: fibroblast growth factor receptor signalling and the consequences of pathway malfunction. Trends Cell Biol 25:221-233.

Casci T, Vinos J, and Freeman M. 1999. Sprouty, an intracellular inhibitor of Ras signaling. Cell 96:655-665.

Cha SK, Hu MC, Kurosu H, Kuro-o M, Moe O, and Huang CL. 2009. Regulation of renal outer medullary potassium channel and renal $\mathrm{K}(+)$ excretion by klotho. Molecular Pharmacology 76:38-46.

Chang Q, Hoefs S, van der Kemp AW, Topala CN, Bindels RJ, and Hoenderop JG. 2005. The beta-glucuronidase klotho hydrolyzes and activates the TRPV5 channel. Science 310:490-493.

Chen M, and He J. 2004. Effect of bFGF on healing of wound dehiscence of cesarean section. Central Plains Medical Journal 31:12-13. 
681 Coleman SJ, Bruce C, Chioni AM, Kocher HM, and Grose RP. 2014. The ins and outs of

682

683

684

685

686

687

688

689

690

691

692

693

694

695

696

697

698

699

700

701

702

703

704

705

706

707

708

709

710

711

712

713

714

715

716

717

718

719

720

721

722

723

724

725 fibroblast growth factor receptor signalling. Clin Sci (Lond) 127:217-231.

Connell BJ, and Lortat-Jacob H. 2013. Human immunodeficiency virus and heparan sulfate: from attachment to entry inhibition. Frontiers in Immunology 4.

Conoyer JM, Kaylie DM, and Jackson CG. 2007. Otologic surgery following ear trauma. Otolaryngology-Head and Neck Surgery 137:757-761.

Courty J, Dauchel MC, Caruelle D, Perderiset M, and Barritault D. 1991. Mitogenic properties of a new endothelial cell growth factor related to pleiotrophin. Biochem Biophys Res Commun 180:145-151.

Davies BR, Fernig DG, Barraclough R, and Rudland PS. 1996. Effect on tumorigenicity and metastasis of transfection of a diploid benign rat mammary epithelial cell line with DNA corresponding to the mRNA for basic fibroblast growth factor. International Journal of Cancer 65:104-111.

Delehedde M, Lyon M, Sergeant N, Rahmoune H, and Fernig DG. 2001. Proteoglycans: pericellular and cell surface multireceptors that integrate external stimuli in the mammary gland. Journal of mammary gland biology and neoplasia 6:253-273.

DeVore DL, Horvitz HR, and Stern MJ. 1995. An FGF receptor signaling pathway is required for the normal cell migrations of the sex myoblasts in C. elegans hermaphrodites. Cell 83:611-620.

Doherty P, and Walsh FS. 1996. CAM-FGF receptor interactions: a model for axonal growth. Mol Cell Neurosci 8:99-111.

Dorey K, and Amaya E. 2010. FGF signalling: diverse roles during early vertebrate embryogenesis. Development 137:3731-3742.

Dreyfuss JL, Regatieri CV, Jarrouge TR, Cavalheiro RP, Sampaio LO, and Nader HB. 2009. Heparan sulfate proteoglycans: structure, protein interactions and cell signaling. Anais Da Academia Brasileira De Ciencias 81:409-429.

Duchesne L, Octeau V, Bearon RN, Beckett A, Prior IA, Lounis B, and Fernig DG. 2012. Transport of fibroblast growth factor 2 in the pericellular matrix is controlled by the spatial distribution of its binding sites in heparan sulfate. Plos Biology 10:e1001976.

Duchesne L, Tissot B, Rudd TR, Dell A, and Fernig DG. 2006. N-glycosylation of fibroblast growth factor receptor 1 regulates ligand and heparan sulfate co-receptor binding. $J$ Biol Chem 281:27178-27189.

Faham S, Hileman RE, Fromm JR, Linhardt RJ, and Rees DC. 1996. Heparin structure and interactions with basic fibroblast growth factor. Science 271:1116-1120.

Fernig DG, and Gallagher JT. 1994. Fibroblast growth factors: an information network controlling tissue growth, morphogenesis and repair. Prog Growth Factor Res 5:353377.

Fleming TC, Wolf FW, and Garriga G. 2005. Sensitized genetic backgrounds reveal a role for C. elegans FGF EGL-17 as a repellent for migrating CAN neurons. Development 132:4857-4867.

Gallagher J. 2015. Fell-Muir Lecture: Heparan sulphate and the art of cell regulation: a polymer chain conducts the protein orchestra. International journal of experimental pathology 96:203-231.

Goetz R, and Mohammadi M. 2013. Exploring mechanisms of FGF signalling through the lens of structural biology. Nature Reviews Molecular Cell Biology 14:166-180. 
726

727

728

729

730

731

732

733

734

735

736

737

738

739

740

741

742

743

744

745

746

747

748

749

750

751

752

753

754

755

756

757

758

759

760

761

762

763

764

765

766

767

768

769

770

Goldberg JD, Zheng J, Castro-Malaspina H, Jakubowski AA, Heller G, van den Brink MR, and Perales MA. 2013. Palifermin is efficacious in recipients of TBI-based but not chemotherapy-based allogeneic hematopoietic stem cell transplants. Bone marrow transplantation 48:99-104.

Goldfarb M. 2005. Fibroblast growth factor homologous factors: evolution, structure, and function. Cytokine Growth Factor Rev 16:215-220.

Goodman SJ, Branda CS, Robinson MK, Burdine RD, and Stern MJ. 2003. Alternative splicing affecting a novel domain in the C. elegans EGL-15 FGF receptor confers functional specificity. Development 130:3757-3766.

Guo X. 2006. Clinical Observation on Recombinant Human Basic Fibroblastic Growth Factor Treating $\Pi^{\circ} \quad$ Burn. Modern Diagnosis and Treatment 17:215-216.

Hacohen N, Kramer S, Sutherland D, Hiromi Y, and Krasnow MA. 1998. sprouty encodes a novel antagonist of FGF signaling that patterns apical branching of the Drosophila airways. Cell 92:253-263.

Hakuba N, Iwanaga M, Tanaka S, Hiratsuka Y, Kumabe Y, Konishi M, Okanoue Y, Hiwatashi $\mathrm{N}$, and Wada T. 2010. Basic fibroblast growth factor combined with atelocollagen for closing chronic tympanic membrane perforations in 87 patients. Otology \& Neurotology 31:118-121.

Hirano S, Kishimoto Y, Suehiro A, Kanemaru S, and Ito J. 2008. Regeneration of aged vocal fold: first human case treated with fibroblast growth factor. The Laryngoscope 118:2254-2259.

Hirano S, Tateya I, Kishimoto Y, Kanemaru S, and Ito J. 2012. Clinical trial of regeneration of aged vocal folds with growth factor therapy. The Laryngoscope 122:327-331.

Horton AC, Mahadevan NR, Ruvinsky I, and Gibson-Brown JJ. 2003. Phylogenetic analyses alone are insufficient to determine whether genome duplication(s) occurred during early vertebrate evolution. J Exp Zool B Mol Dev Evol 299:41-53.

Huang P, and Stern MJ. 2004. FGF signaling functions in the hypodermis to regulate fluid balance in C. elegans. Development 131:2595-2604.

Ito S, Kinoshita S, Shiraishi N, Nakagawa S, Sekine S, Fujimori T, and Nabeshima YI. 2000. Molecular cloning and expression analyses of mouse betaklotho, which encodes a novel Klotho family protein. Mechanisms of development 98:115-119.

Itoh N. 2007. The Fgf families in humans, mice, and zebrafish: their evolutional processes and roles in development, metabolism, and disease. Biol Pharm Bull 30:1819-1825.

Itoh N, and Ornitz DM. 2004. Evolution of the Fgf and Fgfr gene families. Trends Genet 20:563-569.

Itoh N, and Ornitz DM. 2008. Functional evolutionary history of the mouse Fgf gene family. Dev Dyn 237:18-27.

Itoh N, and Ornitz DM. 2011. Fibroblast growth factors: from molecular evolution to roles in development, metabolism and disease. J Biochem 149:121-130.

Izvolsky KI, Shoykhet D, Yang Y, Yu Q, Nugent MA, and Cardoso WV. 2003. Heparan sulfateFGF10 interactions during lung morphogenesis. Dev Biol 258:185-200.

Jiang XW, Zhang Y, Zhang H, Lu K, Yang SK, and Sun GL. 2013. Double-blind, randomized, controlled clinical trial of the effects of diosmectite and basic fibroblast growth factor paste on the treatment of minor recurrent aphthous stomatitis. Oral Surgery, Oral Medicine, Oral Pathology and Oral Radiology 116:570-575.

Peer] reviewing PDF | (2015:09:6793:1:1:NEW 30 Nov 2015) 
771

772

773

774

775

776

777

778

779

780

781

782

783

784

785

786

787

788

789

790

791

792

793

794

795

796

797

798

799

800

801

802

803

804

805

806

807

808

809

810

811

812

813

814

815
Kan M, Wang F, Xu J, Crabb JW, Hou J, and McKeehan WL. 1993. An essential heparinbinding domain in the fibroblast growth factor receptor kinase. Science 259:19181921.

Kato M, Wang H, Kainulainen V, Fitzgerald ML, Ledbetter S, Ornitz DM, and Bernfield M. 1998. Physiological degradation converts the soluble syndecan-1 ectodomain from an inhibitor to a potent activator of FGF-2. Nat Med 4:691-697.

Kawaguchi H, Oka H, Jingushi S, Izumi T, Fukunaga M, Sato K, Matsushita T, and Nakamura K. 2010. A local application of recombinant human fibroblast growth factor 2 for tibial shaft fractures: A randomized, placebo-controlled trial. Journal of bone and mineral research : the official journal of the American Society for Bone and Mineral Research 25:2735-2743.

Kharitonenkov A, Dunbar JD, Bina HA, Bright S, Moyers JS, Zhang C, Ding L, Micanovic R, Mehrbod SF, Knierman MD, Hale JE, Coskun T, and Shanafelt AB. 2008. FGF-21/FGF21 receptor interaction and activation is determined by betaKlotho. J Cell Physiol 215:1-7.

Kharitonenkov A, and Shanafelt AB. 2008. Fibroblast growth factor-21 as a therapeutic agent for metabolic diseases. BioDrugs 22:37-44.

Kharitonenkov A, and Shanafelt AB. 2009. FGF21: a novel prospect for the treatment of metabolic diseases. Curr Opin Investig Drugs 10:359-364.

Kim I, Moon SO, Yu KH, Kim UH, and Koh GY. 2001. A novel fibroblast growth factor receptor-5 preferentially expressed in the pancreas. Biochimica Et Biophysica ActaGene Structure and Expression 1518:152-156.

Kirkpatrick CA, and Selleck SB. 2007. Heparan sulfate proteoglycans at a glance. Journal of Cell Science 120:1829-1832.

Kitamura M, Akamatsu M, Machigashira M, Hara Y, Sakagami R, Hirofuji T, Hamachi T, Maeda K, Yokota M, Kido J, Nagata T, Kurihara H, Takashiba S, Sibutani T, Fukuda M, Noguchi T, Yamazaki K, Yoshie H, Ioroi K, Arai T, Nakagawa T, Ito K, Oda S, Izumi Y, Ogata Y, Yamada S, Shimauchi H, Kunimatsu K, Kawanami M, Fujii T, Furuichi Y, Furuuchi T, Sasano T, Imai E, Omae M, Watanuki M, and Murakami S. 2011. FGF-2 stimulates periodontal regeneration: results of a multi-center randomized clinical trial. Journal of dental research 90:35-40.

Kokel M, Borland CZ, DeLong L, Horvitz HR, and Stern MJ. 1998. clr-1 encodes a receptor tyrosine phosphatase that negatively regulates an FGF receptor signaling pathway in Caenorhabditis elegans. Genes Dev 12:1425-1437.

Kubo S, Inui T, Hasegawa H, and Yoshimine T. 2005. Repair of intractable cerebrospinal fluid rhinorrhea with mucosal flaps and recombinant human basic fibroblast growth factor: technical case report. Neurosurgery 56:E627.

Kumagai M, Marui A, Tabata Y, Takeda T, Yamamoto M, Yonezawa A, Tanaka S, Yanagi S, Ito-Ihara T, Ikeda T, Murayama T, Teramukai S, Katsura T, Matsubara K, Kawakami K, Yokode M, Shimizu A, and Sakata R. 2015. Safety and efficacy of sustained release of basic fibroblast growth factor using gelatin hydrogel in patients with critical limb ischemia. Heart and vessels.

Kuro-o M. 2012. Klotho and bKlotho. Landes Bioscience:25-40.

Kuro-o M, Matsumura Y, Aizawa H, Kawaguchi H, Suga T, Utsugi T, Ohyama Y, Kurabayashi M, Kaname T, Kume E, Iwasaki H, Iida A, Shiraki-Iida T, Nishikawa S, Nagai R, and 
816

817

818

819

820

821

822

823

824

825

826

827

828

829

830

831

832

833

834

835

836

837

838

839

840

841

842

843

844

845

846

847

848

849

850

851

852

853

854

855

856

857

858

859

860
Nabeshima YI. 1997. Mutation of the mouse klotho gene leads to a syndrome resembling ageing. Nature 390:45-51.

Kurosu H, Choi M, Ogawa Y, Dickson AS, Goetz R, Eliseenkova AV, Mohammadi M, Rosenblatt KP, Kliewer SA, and Kuro-o M. 2007. Tissue-specific expression of betaKlotho and fibroblast growth factor (FGF) receptor isoforms determines metabolic activity of FGF19 and FGF21. J Biol Chem 282:26687-26695.

Kurosu H, Ogawa Y, Miyoshi M, Yamamoto M, Nandi A, Rosenblatt KP, Baum MG, Schiavi S, $\mathrm{Hu}$ MC, Moe OW, and Kuro-o M. 2006. Regulation of fibroblast growth factor-23 signaling by klotho. J Biol Chem 281:6120-6123.

Li LY, Safran M, Aviezer D, Bohlen P, Seddon AP, and Yayon A. 1994. Diminished heparin binding of a basic fibroblast growth factor mutant is associated with reduced receptor binding, mitogenesis, plasminogen activator induction, and in vitro angiogenesis. Biochemistry 33:10999-11007.

Li X, Xu H, Zhao W, Zheng Q, Huang Y, Wu X, and Liu C. 2002. Pharmacokinetic study of recombinant human acidic fibroblast growth factor in rabbits by skin external use. Acta Pharmaceutica Sinica 37:424-427.

Lin BC, Wang, M., Blackmore, C., Desnoyers, L.R. 2007. Liver-specific activities of FGF19 require Klotho beta.J Biol Chem 282:27277-27284.

Lin XH. 2004. Functions of heparan sulfate proteoglycans in cell signaling during development. Development 131:6009-6021.

Liu X, Jiang N, and Tan C. 2005. The clinical study of recombinant human basic fibroblast growth factor in stimulating the wound surface healing. Acta Academiae Medicinae Jiangxi 43:92-94.

Lo TW, Branda CS, Huang P, Sasson IE, Goodman SJ, and Stern MJ. 2008. Different isoforms of the C. elegans FGF receptor are required for attraction and repulsion of the migrating sex myoblasts. Dev Biol 318:268-275.

Lohmander LS, Hellot S, Dreher D, Krantz EFW, Kruger DS, Guermazi A, and Eckstein F. 2014. Intraarticular sprifermin (recombinant human fibroblast growth factor 18) in knee osteoarthritis. Arthritis \& Rheumatology 66:1820-1831.

Lou Z, Wang Y, and Yu G. 2014. Effects of basic fibroblast growth factor dose on traumatic tympanic membrane perforation. Growth factors 32:150-154.

Lou ZC, and Wang YB. 2013. Healing outcomes of large (>50\%) traumatic membrane perforations with inverted edges following no intervention, edge approximation and fibroblast growth factor application; a sequential allocation, three-armed trial. Clinical Otolaryngology 38:289-296.

Lu B, Jin H, and Pang X. 2006. Effect of recombinant bovine basic fibroblast growth factor (rb-bFGF) on the healing of plastic sugery incision. Chinese Journal of Aesthetic Medicine 15:41-43.

Maciag T, Mehlman T, Friesel R, and Schreiber AB. 1984. Heparin binds endothelial cell growth factor, the principal endothelial cell mitogen in bovine brain. Science 225:932-935.

Martin A, David, V., Quarles, L.D. 2012. Regulation and function of the FGF23/Klotho endocrine pathways. Physiol Rev 92:131-155.

Matsumine H. 2015. Treatment of skin avulsion injuries with basic fibroblast growth factor. Plastic and reconstructive surgery Global open 3:e371. 
861

862

863

864

865

866

867

868

869

870

871

872

873

874

875

876

877

878

879

880

881

882

883

884

885

886

887

888

889

890

891

892

893

894

895

896

897

898

899

900

901

902

903

904

905

906
Metcalfe AD, and Ferguson MW. 2007. Tissue engineering of replacement skin: the crossroads of biomaterials, wound healing, embryonic development, stem cells and regeneration. Journal of the Royal Society, Interface / the Royal Society 4:413-437.

Mori Y, Saito T, Chang SH, Kobayashi H, Ladel CH, Guehring H, Chung UI, and Kawaguchi H. 2014. Identification of fibroblast growth factor-18 as a molecule to protect adult articular cartilage by gene expression profiling. J Biol Chem 289:10192-10200.

Murphy KJ, Merry CL, Lyon M, Thompson JE, Roberts IS, and Gallagher JT. 2004. A new model for the domain structure of heparan sulfate based on the novel specificity of K5 lyase. J Bio Chem 279:27239-27245.

Ono I, Akasaka Y, Kikuchi R, Sakemoto A, Kamiya T, Yamashita T, and Jimbow K. 2007. Basic fibroblast growth factor reduces scar formation in acute incisional wounds. Wound Repair and Regeneration 15:617-623.

Ori A, Free P, Courty J, Wilkinson MC, and Fernig DG. 2009. Identification of heparinbinding sites in proteins by selective labeling. Molecular \& Cellular Proteomics 8:2256-2265.

Ori A, Wilkinson MC, and Fernig DG. 2008. The heparanome and regulation of cell function: structures, functions and challenges. Frontiers in Bioscience 13:4309-4338.

Ori A, Wilkinson MC, and Fernig DG. 2011. A systems biology approach for the investigation of the heparin/heparan sulfate interactome. J Biol Chem 286:19892-19904.

Ornitz DM. 2000. FGFs, heparan sulfate and FGFRs: complex interactions essential for development. Bioessays 22:108-112.

Ornitz DM, and Itoh N. 2001. Fibroblast growth factors. Genome Biol 2:REVIEWS3005.

Ornitz DM, Xu JS, Colvin JS, McEwen DG, MacArthur CA, Coulier F, Gao GX, and Goldfarb M. 1996. Receptor specificity of the fibroblast growth factor family. J Biol Chem 271:15292-15297.

Patel M, Margaron Y, Fradet N, Yang Q, Wilkes B, Bouvier M, Hofmann K, and Cote JF. 2010. An evolutionarily conserved autoinhibitory molecular switch in ELMO proteins regulates Rac signaling. Curr Biol 20:2021-2027.

Pharmacopeia. 2015. Recombinant bovine basophilic Fibroblast growth factor for external use (including liquid and eye drops): China Medical and Pharmacological Science and Technology Publishing Company.

Polanska UM, Duchesne L, Harries JC, Fernig DG, and Kinnunen TK. 2009a. N-Glycosylation regulates fibroblast growth factor receptor/EGL-15 activity in Caenorhabditis elegans in vivo.J Biol Chem 284:33030-33039.

Polanska UM, Edwards E, Fernig DG, and Kinnunen TK. 2011. The Cooperation of FGF Receptor and Klotho Is Involved in Excretory Canal Development and Regulation of Metabolic Homeostasis in Caenorhabditis elegans. J Biol Chem 286:5657-5666.

Polanska UM, Fernig DG, and Kinnunen T. 2009b. Extracellular interactome of the FGF receptor-ligand system: complexities and the relative simplicity of the worm. Dev Dyn 238:277-293.

Powell AK, Fernig DG, and Turnbull JE. 2002. Fibroblast growth factor receptors 1 and 2 interact differently with heparin/heparan sulfate - Implications for dynamic assembly of a ternary signaling complex.J Biol Chem 277:28554-28563.

Presta M, Maier JAM, Rusnati M, and Ragnotti G. 1989. Basic fibroblast growth factor is released from endothelial extracellular matrix in a biologically active form. J Cell Physiol 140:68-74. 
907 Ramani VC, Purushothaman A, Stewart MD, Thompson CA, Vlodavsky I, Au JL, and

908

909

910

911

912

913

914

915

916

917

918

919

920

921

922

923

924

925

926

927

928

929

930

931

932

933

934

935

936

937

938

939

940

941

942

943

944

945

946

947

948

949

950

951 Sanderson RD. 2013. The heparanase/syndecan-1 axis in cancer: mechanisms and therapies. FEBS J 280:2294-2306.

Rapraeger AC, Krufka A, and Olwin BB. 1991. Requirement of heparan sulfate for bFGFmediated fibroblast growth and myoblast differentiation. Science 252:1705-1708.

Ren C, and Shun C. 2002. An observation of the effect of bFGF on recurrent oral ulcer. Journal of Clinical Stomatology 18:389-390.

Robson MC, Phillips LG, Lawrence WT, Bishop JB, Youngerman JS, Hayward PG, Broemeling LD, and Heggers JP. 1992. The safety and effect of topically applied recombinant basic fibroblast growth factor on the healing of chronic pressure sores. Annals of surgery 216:401-408.

Rockwell WB, Cohen IK, and Ehrlich HP. 1989. Keloids and hypertrophic scars: a comprehensive review. Plastic and Reconstructive Surgery 84:827-837.

Roubin R, Naert K, Popovici C, Vatcher G, Coulier F, Thierry-Mieg J, Pontarotti P, Birnbaum D, Baillie D, and Thierry-Mieg D. 1999. let-756, a C. elegans fgf essential for worm development. Oncogene 18:6741-6747.

Rudland PS, Seifert W, and Gospodarowicz D. 1974. Growth control in cultured mouse fibroblasts: induction of the pleiotypic and mitogenic responses by a purified growth factor. Proc Natl Acad Sci US A 71:2600-2604.

Rusnati M, Tanghetti E, Dell'Era P, Gualandris A, and Presta M. 1997. alphavbeta3 integrin mediates the cell-adhesive capacity and biological activity of basic fibroblast growth factor (FGF-2) in cultured endothelial cells. Mol Biol Cell 8:2449-2461.

Schlessinger J, Plotnikov AN, Ibrahimi OA, Eliseenkova AV, Yeh BK, Yayon A, Linhardt RJ, and Mohammadi M. 2000. Crystal structure of a ternary FGF-FGFR-heparin complex reveals a dual role for heparin in FGFR binding and dimerization. Molecular cell 6:743-750.

Shing Y, Folkman J, Sullivan R, Butterfield C, Murray J, and Klagsbrun M. 1984. Heparin affinity: purification of a tumor-derived capillary endothelial cell growth factor. Science 223:1296-1299.

Sleeman M, Fraser J, McDonald M, Yuan SN, White D, Grandison P, Kumble K, Watson JD, and Murison JG. 2001. Identification of a new fibroblast growth factor receptor, FGFR5. Gene 271:171-182.

$\mathrm{Su}$ N, Du X, and Chen L. 2008. FGF signaling: its role in bone development and human skeleton diseases. Frontiers in Bioscience : a journal and virtual library 13:28422865.

Suh JM, Jonker JW, Ahmadian M, Goetz R, Lackey D, Osborn O, Huang ZF, Liu WL, Yoshihara E, van Dijk TH, Havinga R, Fan WW, Yin YQ, Yu RT, Liddle C, Atkins AR, Olefsky JM, Mohammadi M, Downes M, and Evans RM. 2014. Endocrinization of FGF1 produces a neomorphic and potent insulin sensitizer. Nature 513:436-439.

Taylor KR, and Gallo RL. 2006. Glycosaminoglycans and their proteoglycans: hostassociated molecular patterns for initiation and modulation of inflammation. Faseb Journal 20:9-22.

Thompson LD, Pantoliano MW, and Springer BA. 1994. Energetic characterization of the basic fibroblast growth factor-heparin interaction: identification of the heparin binding domain. Biochemistry 33:3831-3840. 
952 Trowell OA, and Willmer EN. 1939. Studies on the growth of tissues in vitro VI. The effects 953 of some tissue extracts on the growth of periosteal fibroblasts. Journal of 954 Experimental Biology 16:60-70.

955 Tumova S, Woods A, and Couchman JR. 2000. Heparan sulfate proteoglycans on the cell 956 surface: versatile coordinators of cellular functions. International Journal of 957 Biochemistry \& Cell Biology 32:269-288.

958 Turnbull J, Powell A, and Guimond S. 2001. Heparan sulfate: decoding a dynamic 959

960

961

962

963

964

965

966

967

968

969

970

971

972

973

974

975

976

977

978

979

980

981

982

983

984

985

986

987

988

989

990

991

992

993

994

995

996

Turner N, and Grose R. 2010. Fibroblast growth factor signalling: from development to cancer. Nature Reviews Cancer 10:116-129.

Uchi H, Igarashi A, Urabe K, Koga T, Nakayama J, Kawamori R, Tamaki K, Hirakata H, Ohura T, and Furue M. 2009. Clinical efficacy of basic fibroblast growth factor (bFGF) for diabetic ulcer. European Journal of Dermatology: EJD 19:461-468.

Urakawa I, Yamazaki Y, Shimada T, Iijima K, Hasegawa H, Okawa K, Fujita T, Fukumoto S, and Yamashita T. 2006. Klotho converts canonical FGF receptor into a specific receptor for FGF23. Nature 444:770-774.

Vera-Llonch M, Oster G, Hagiwara M, and Sonis S. 2006. Oral mucositis in patients undergoing radiation treatment for head and neck carcinoma - Risk factors and clinical consequences. Cancer 106:329-336.

Vlodavsky I, Folkman J, Sullivan R, Fridman R, Ishai-Michaeli R, Sasse J, and Klagsbrun M. 1987. Endothelial cell-derived basic fibroblast growth factor: synthesis and deposition into subendothelial extracellular matrix. Proc Natl Acad Sci U SA 84:2292-2296.

Wiedemann M, and Trueb B. 2000. Characterization of a novel protein (FGFRL1) from human cartilage related to FGF receptors. Genomics 69:275-279.

Worthington HV, Clarkson JE, Bryan G, Furness S, Glenny AM, Littlewood A, McCabe MG, Meyer S, and Khalid T. 2011. Interventions for preventing oral mucositis for patients with cancer receiving treatment. Cochrane Database of Systematic Reviews.

Wu X, Ge H, Gupte J, Weiszmann J, Shimamoto G, Stevens J, Hawkins N, Lemon B, Shen W, Xu J, Veniant MM, Li YS, Lindberg R, Chen JL, Tian H, and Li Y. 2007. Co-receptor requirements for fibroblast growth factor-19 signaling. J Biol Chem 282:2906929072.

Wu X, Li X, Su Z, Zheng Q, and Wu S. 2005. For improving the condition of bFGF, which is unstable, short half-life and immunoreaction, the bFGF mutant has been designed to replace Cys-25/69/92 with serine residues. The bFGF mutant has been shown that the mutant could induce the Balb/c cell proliferation as same level as wild-type. China Biotechnology 25:32-35.

Wu X, Su Z, Zheng Q, Huang Y, Ya D, and Li X. 2004. For increasing the yield of aFGF, the truncated aFGF (shaFGF), which has been eliminated the First 19 amino acides at Nterminal, had been produced up to $25 \%$ of total cellular protein in E.coli. Both ShaFGF and wild-type aFGF (haFGF) have been shown to have similar level of mitogenic activity by using MTT method. Journal of China Pharmaceutical University 35:470-473.

Xu D, and Esko JD. 2014. Demystifying heparan sulfate-protein interactions. Annual review of biochemistry 83:129-157. 
997

998

999

1000

1001

1002

1003

1004

1005

1006

1007

1008

1009

1010

1011

1012

1013

1014

1015

1016

1017

1018

1019

1020

1021

1022

1023

1024

1025

1026

1027

1028

1029

1030

1031

1032

1033

1034

1035

1036

1037

1038

1039

Xu H, Li X, Zheng Q, Huang Y, Zhao W, Yao C, Wu X, and Huang Z. 2003. Study on Long-term Toxicity of Recombinant Human Acidic Fibroblast Growth Factor in Rabbits. Journal of China Pharmaceutical University 34:46-50.

$\mathrm{Xu}$ J, Li Q, and Fan Z. 2000. Acelerated healing of skin wounds in donor area using bFGF : arandomized controlled report of 34 cases. Chinese Journal of Anatomy and Clinical Practice 5:28-29.

Xu RY, Ori A, Rudd TR, Uniewicz KA, Ahmed YA, Guimond SE, Skidmore MA, Siligardi G, Yates EA, and Fernig DG. 2012. Diversification of the structural determinants of fibroblast growth factor-heparin interactions implications for binding specificity. $J$ Biol Chem 287:40061-40073.

Xu RY, Rudd TR, Hughes AJ, Siligardi G, Fernig DG, and Yates EA. 2013. Analysis of the fibroblast growth factor receptor (FGFR) signalling network with heparin as coreceptor: evidence for the expansion of the core FGFR signalling network. FEBS J 280:2260-2270.

Yanagishita M, and Hascall VC. 1992. Cell surface heparan sulfate proteoglycans. J Biol Chem 267:9451-9454.

Yao C, Zheng Q, Xu H, Zhao W, Wu X, Su Z, Huang Y, and Li X. 2006. The stability of recombinant human acid fibroblast growth factor Chinese. Journal of Modern Applied Pharmacy 23:358-360.

Yayon A, Klagsbrun M, Esko JD, Leder P, and Ornitz DM. 1991. Cell surface, heparin-like molecules are required for binding of basic fibroblast growth factor to its high affinity receptor. Cell 64:841-848.

Yung S, and Chan TM. 2007. Glycosaminoglycans and proteoglycans: Overlooked entities? Peritoneal Dialysis International 27:S104-S109.

Zang X, Zha Z, and Yao P. 2005. Effect of FGF organism protein sponge on promoting the repair of traumatic ulcer. Journal of Clinical Orthopaedics 8:110-112.

Zhang J, and Li Y. 2014. Fibroblast growth factor 21, the endocrine FGF pathway and novel treatments for metabolic syndrome. Drug Discov Today 19:579-589.

Zhang JD, Cousens LS, Barr PJ, and Sprang SR. 1991. Three-dimensional structure of human basic fibroblast growth factor, a structural homolog of interleukin 1 beta. Proc Natl Acad Sci U S A 88:3446-3450.

Zhang XQ, Ibrahimi OA, Olsen SK, Umemori H, Mohammadi M, and Ornitz DM. 2006. Receptor specificity of the fibroblast growth factor family - The complete mammalian FGF family. J Biol Chem 281:15694-15700.

Zhao J, Fu X, Chen W, Sun T, Zhen S, Weng L, and Zhang Y. 2004. The wild-type aFGF has been shown to significantly induce the cutaneous cell proliferation, whereas the truncated aFGF, which had been truncated the N-terminal sequence "21NYKKPKL27", had no apparent impact on cell proliferation, which may reduce the effect of aFGF on the induction of tumour. Chin Crit Care Med 16:458-459.

Zhu X, Komiya H, Chirino A, Faham S, Fox GM, Arakawa T, Hsu BT, and Rees DC. 1991. Three-dimensional structures of acidic and basic fibroblast growth factors. Science 251:90-93. 
1

Phylogenetic relationship of the FGFs based on amino acid sequence

According to amino acid sequence, Dendroscope was used to show that FGF family is divided into seven subfamilies. The branch lengths relates directly to the evolutionary relationship of FGFs.

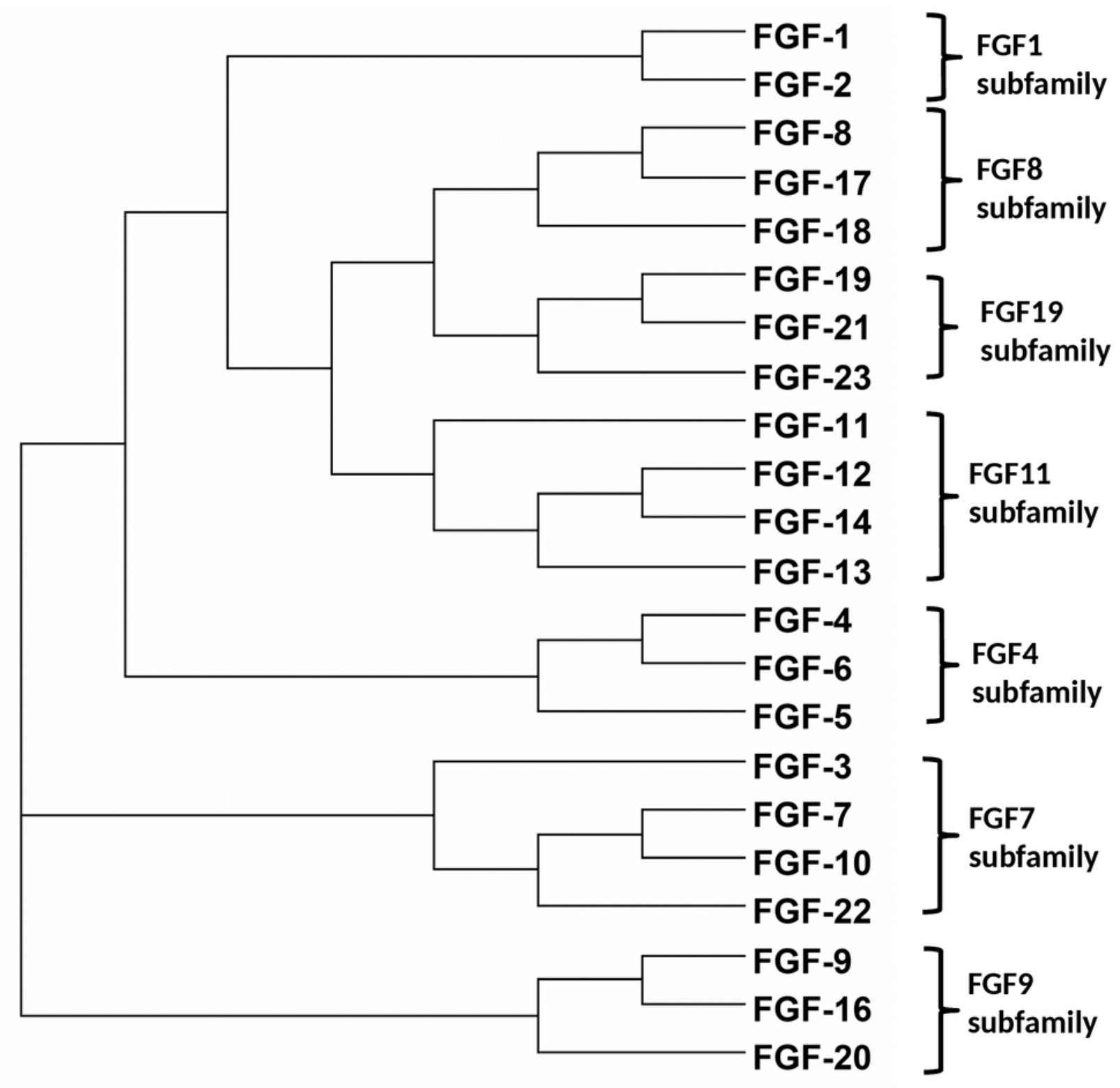


2

Schematic diagram of the core structure unit of the beta-trefoil

PDB ID: 2FGF ( Zhang et al. 1991 ) . (A) The first ascending strand ( $\beta A$ ) is connected to a descending strand $(\beta B)$. The following "horizontal" strand $(\beta C)$ finishes by returns strand $(\beta D)$. (B) Three of these units arranged around a pseudo three-fold axis of symmetry form the $\beta$ trefoil.
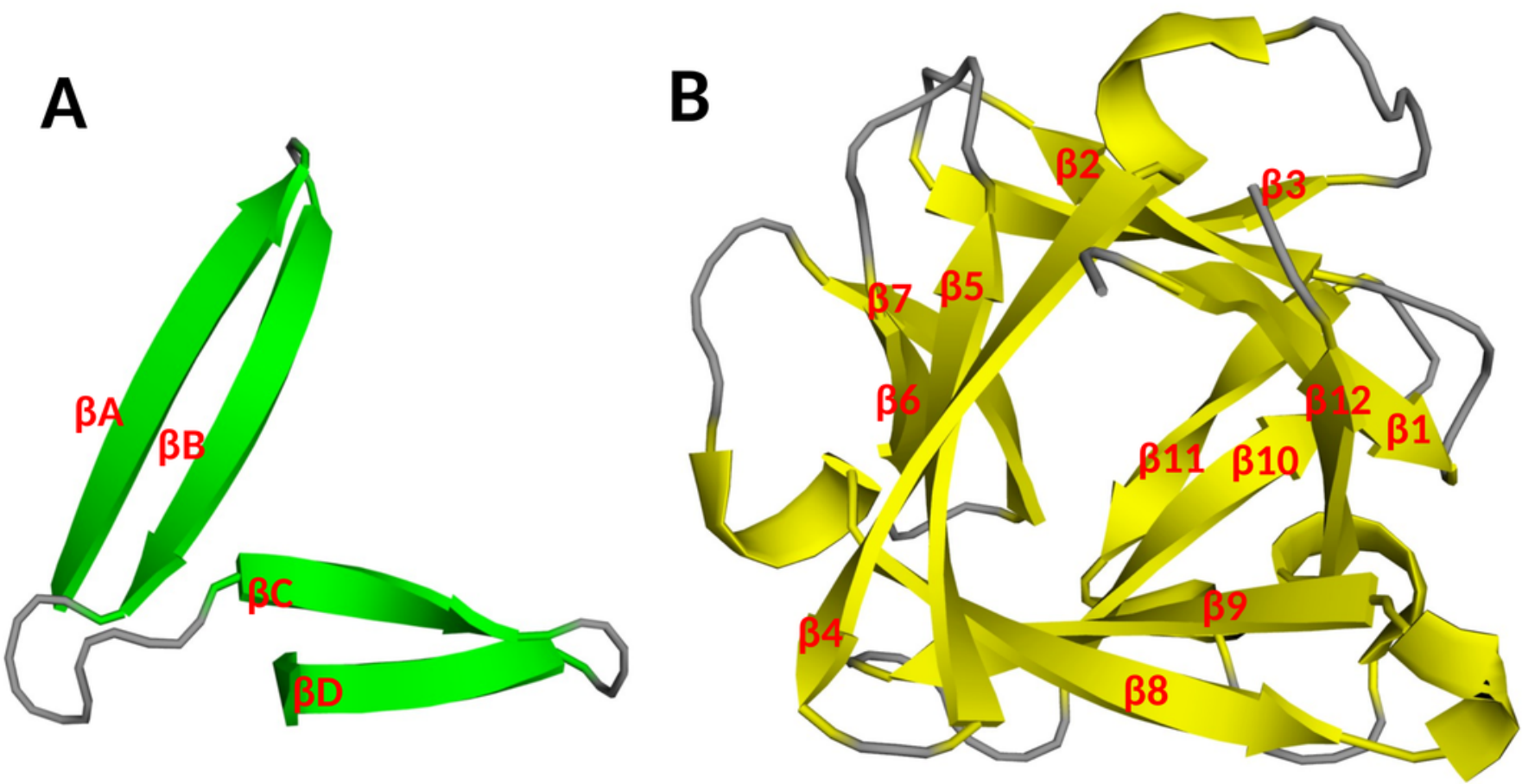


\section{Figure 3 (on next page)}

FGF interactions with FGFR and heparin/heparan sulfate

(A): Ternary structure of FGF-FGFR-heparin complex (1FQ9 ( Schlessinger et al. 2000a ) ). FGFs interact with the D2 and D3 domain and the linker between these two domains. A heparin octasaccharide, binds to the conserved canonical binding site on FGFs, which is opposite to the N- terminal, and to the basic canyon in the FGFR. (B): Heparin binding sites of FGF2 (1FQ9) identified by a selective labelling approach ( Ori et al. 2009). Three binding sites were recognised: the canonical binding site (HBS1), and two secondary and relatively weaker binding sites (HBS2 and HBS3). (C): Heparin binding site of FGF9 (1G82 ( Hecht et al. 2001 ) ). Only the conserved HBS1 was identified, indicating that FGF9 does not possess secondary polysaccharide binding sites ( Xu et al. 2012 ), subsequently confirmed in biophysical experiments ( Migliorini et al. 2015 ). Green indicates the N-terminal of the proteins. Grey is FGFR1. Magenta are FGFs (FGF2 in B and FGF9 in C). The residues in blue are the heparin binding sites of the FGFs. 
(A) PeerJ 2 Manuscript to be reviewed
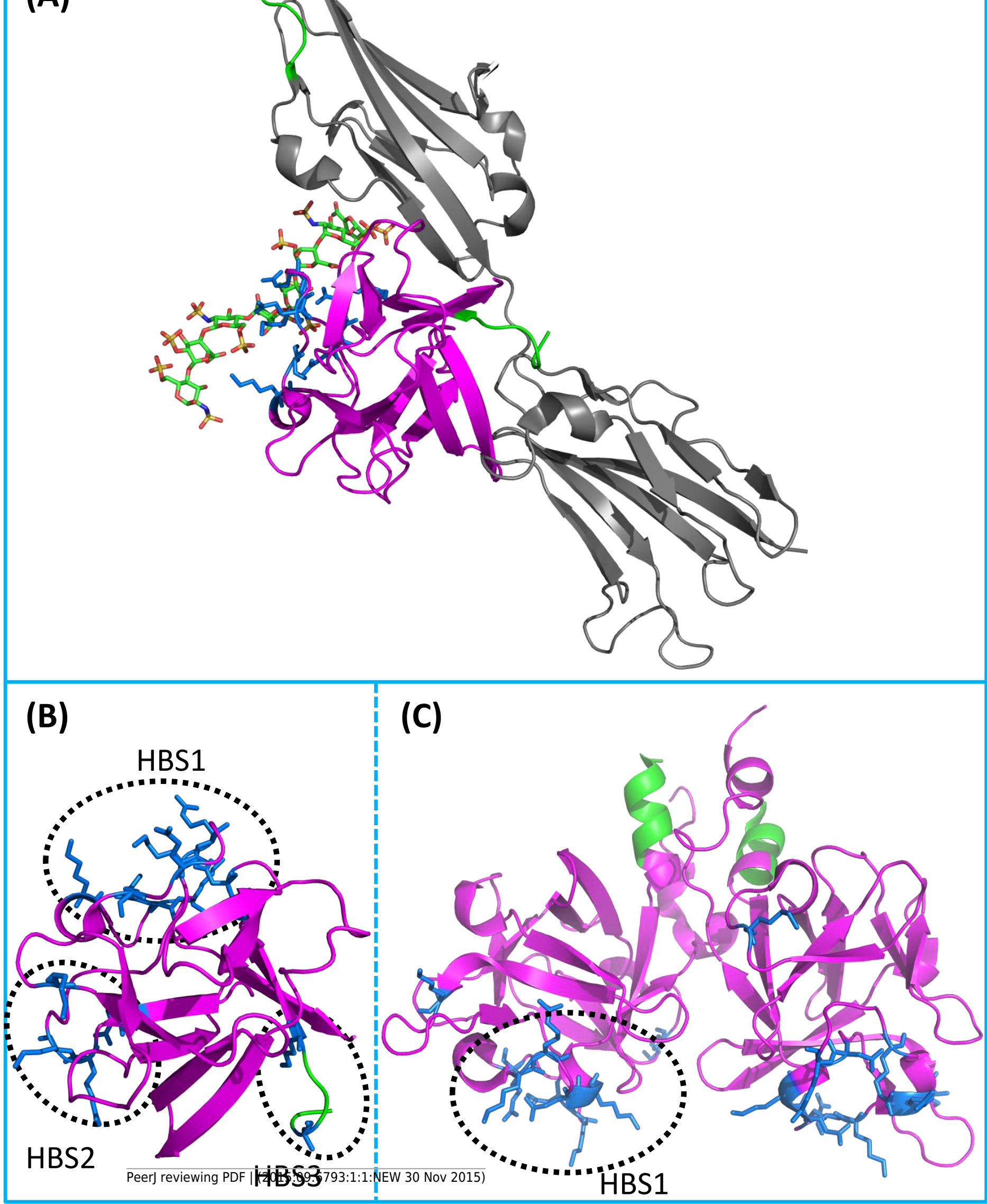


\section{Figure 4(on next page)}

Structures of disaccharide units of HS and heparin

(A): Structure of disaccharide unit of heparin/HS. Top: the glucuronic acid containing disaccharide. This is generally not or only slightly modified by sulfation (in red). Bottom: the iduronic acid containing disaccharide, which always contains an N-sulfated glucosamine (red) and is often further modified by O-sulfation (red). (B): Structure of HS chains. The polysaccharide chain is covalently linked to a serine on the proteoglycan core protein. The sulfate groups are added by sulfotransferases after the GAG chain is polymerised. Due to the hierachical dependence of the post polymerisation reactions and the sulfation of discrete blocks of $\mathrm{N}$-acetylglucosamines by $\mathrm{N}$-deacetylase-N-sulfotransferases (NDSTs), the HS chain has a domain structure of alternating NA (GlcA/GIcNAc), NAS ( one disaccharide in two is Nsulfated) and $\mathrm{S}$ (every glucosamine is $\mathrm{N}$-sulfated) domains. Chain lengths vary from $\sim 25$ disaccharides to over 100. Heparin, a common experimental proxy for heparan sulfate is 30 disaccharides in length and can be considered to be a highly sulfated NS domain. 
(A) Uronic acid
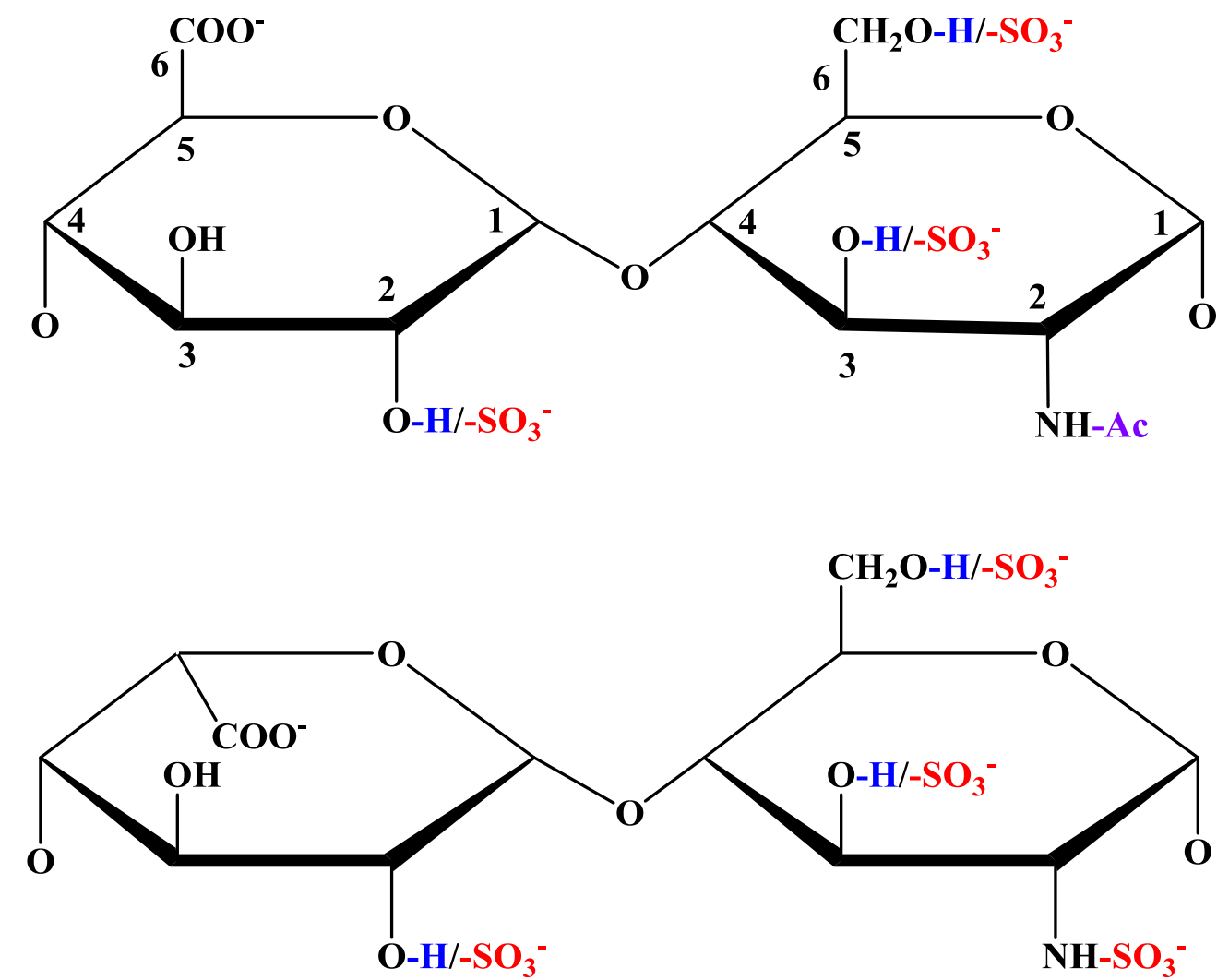

(B)

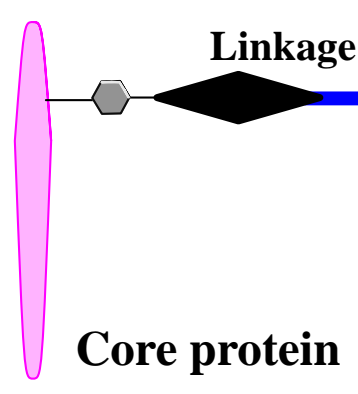

prnsman

NA NAS S NAS NA NAS $S$

Variable sulfation structure 


\section{Table 1 (on next page)}

Therapeutic applications of FGFs.

Summary of the clinical uses of FGFs and the types of study. 


\begin{tabular}{|c|c|c|c|c|c|}
\hline FGF & $\begin{array}{l}\text { Disease/ } \\
\text { condition }\end{array}$ & $\begin{array}{l}\text { Author, } \\
\text { year }\end{array}$ & Type of study & FGF preparation/concentration & Outcome \\
\hline FGF2 & $\begin{array}{l}\text { Burns and } \\
\text { chronic wounds }\end{array}$ & $\begin{array}{l}\text { Liu et al., } \\
2005\end{array}$ & $\begin{array}{l}\text { Prospective, self } \\
\text { controlled } \\
\text { randomisation study }\end{array}$ & FGF2 soaked gauze $\left(20,000 \mathrm{AU} / 100 \mathrm{~cm}^{2}\right)$ & $\begin{array}{l}\text { Healing time was significantly reduced in the FGF2 } \\
\text { treated groups (burns and chronic wounds) compared to } \\
\text { the control group. }\end{array}$ \\
\hline FGF2 & Burns & $\begin{array}{l}\text { Guo et al., } \\
2006\end{array}$ & $\begin{array}{l}\text { Randomised } \\
\text { controlled study }\end{array}$ & FGF2 soaked gauze $\left(20,000 \mathrm{AU} / 100 \mathrm{~cm}^{2}\right)$ & $\begin{array}{l}\text { Healing time was significantly reduced in the FGF2 } \\
\text { treated group }\end{array}$ \\
\hline FGF2 & $\begin{array}{l}\text { Burns (second } \\
\text { degree) }\end{array}$ & $\begin{array}{l}\text { Akita } \text { et al., } \\
2008\end{array}$ & $\begin{array}{l}\text { Randomised } \\
\text { controlled study }\end{array}$ & FGF2 Spray $(30 \mathrm{mg} / 30 \mathrm{~cm} 2$ area $)$ & $\begin{array}{l}\text { Healing time was significantly reduced and quality of } \\
\text { scar improved in the FGF2 treated group. }\end{array}$ \\
\hline FGF2 & $\begin{array}{l}\text { Sutured } \\
\text { wounds } \\
\text { (following skin } \\
\text { tumour } \\
\text { removal) }\end{array}$ & $\begin{array}{l}\text { Ono et al., } \\
2007\end{array}$ & $\begin{array}{l}\text { Prospective, non- } \\
\text { randomised case } \\
\text { control study }\end{array}$ & $\begin{array}{l}\text { Intradermal FGF2 injections (low dose - } 0.1 \\
\text { mg FGF2 per } 1 \mathrm{~cm} \text { of wound, high dose - } \\
1.0 \mathrm{mg} \text { FGF2 per } 1 \mathrm{~cm} \text { wound) and high } \\
\text { FGF2 rinses }(0.1 \mathrm{~mL} \text { of } 10 \mathrm{mg} / \mathrm{mL} \text { FGF2 } \\
\text { solution per } 1 \mathrm{~cm} \text { wound })\end{array}$ & $\begin{array}{l}\text { Scarring was significantly reduced in the FGF2 treated } \\
\text { groups (low and high doses of FGF2). }\end{array}$ \\
\hline FGF2 & $\begin{array}{l}\text { Donor sites } \\
\text { (split thickness } \\
\text { skin grafts) }\end{array}$ & $\begin{array}{l}\text { Xu et al., } \\
2000\end{array}$ & $\begin{array}{l}\text { Randomised self- } \\
\text { controlled trial }\end{array}$ & $\begin{array}{l}\text { FGF2 soaked gauze }\left(150 \mathrm{U} / \mathrm{cm}^{2} \text { for the }\right. \\
\text { first } 3 \text { days followed } 100 \mathrm{U} / \mathrm{cm}^{2} \\
\text { subsequently) }\end{array}$ & $\begin{array}{l}\text { FGF2 significantly reduced healing time and } \\
\text { improved quality of the scar in the treatment group }\end{array}$ \\
\hline FGF2 & $\begin{array}{l}\text { Avulsion } \\
\text { wounds/full- } \\
\text { thickness skin } \\
\text { graft }\end{array}$ & $\begin{array}{l}\text { Matsumine, } \\
2015\end{array}$ & $\begin{array}{l}\text { Prospective, case } \\
\text { series }\end{array}$ & FGF2 spray $\left(1 \mu \mathrm{g} / \mathrm{cm}^{2}\right.$ of graft bed $)$ & $\begin{array}{l}\text { FGF2 application resulted in wound healing with } \\
\text { flexible scars in all cases }\end{array}$ \\
\hline FGF2 & $\begin{array}{l}\text { Sutured } \\
\text { wounds } \\
\text { (cosmetic } \\
\text { surgery) }\end{array}$ & $\begin{array}{l}\text { Lu et al., } \\
2006\end{array}$ & Observational study & $\begin{array}{l}\text { FGF2 soaked gauze (concentration details } \\
\text { not available) }\end{array}$ & $\begin{array}{l}\text { FGF2 application resulted in a significantly shorter } \\
\text { healing time and better quality of scar. }\end{array}$ \\
\hline FGF2 & $\begin{array}{l}\text { Wound } \\
\text { dehiscence } \\
\text { following } \\
\text { Caesarean } \\
\text { section }\end{array}$ & $\begin{array}{l}\text { Chen et al., } \\
2004\end{array}$ & $\begin{array}{l}\text { Randomised } \\
\text { controlled study }\end{array}$ & $\begin{array}{l}\text { FGF2 spray (2-4 mL per application; } \\
\text { details of concentration not available) }\end{array}$ & $\begin{array}{l}\text { FGF2 resulted in a significantly shorter healing time } \\
\text { in wounds }<5 \mathrm{~cm} \text { in the treatment group }\end{array}$ \\
\hline FGF2 & $\begin{array}{l}\text { Tibial shaft } \\
\text { fractures }\end{array}$ & $\begin{array}{l}\text { Kawaguchi } \\
\text { et al., } 2010\end{array}$ & $\begin{array}{l}\text { Randomised, double } \\
\text { blind, placebo- } \\
\text { controlled study }\end{array}$ & $\begin{array}{l}2 \text { percutaneous injections of hydrogel }(0.5 \\
\text { mL each, containing } 0,0.4 \text {, or } 1.2 \mathrm{mg} \text { of } \\
\text { FGF2) }\end{array}$ & $\begin{array}{l}\text { FGF2 accelerated healing of tibial fractures in the } \\
\text { treatment groups }\end{array}$ \\
\hline FGF2 & $\begin{array}{l}\text { Traumatic skin } \\
\text { ulcers }\end{array}$ & $\begin{array}{l}\text { Zang et al., } \\
2005\end{array}$ & $\begin{array}{l}\text { Randomised } \\
\text { controlled study }\end{array}$ & $\begin{array}{l}\text { FGF2 biological protein sponge } \\
\text { (concentration details not available) }\end{array}$ & $\begin{array}{l}\text { FGF2 application resulted in a significantly higher } \\
\text { healing rate in the treatment group. }\end{array}$ \\
\hline FGF2 & $\begin{array}{l}\text { Recurrent } \\
\text { aphthous }\end{array}$ & $\begin{array}{l}\text { Jiang et al., } \\
2013\end{array}$ & $\begin{array}{l}\text { Double blind, } \\
\text { randomised controlled }\end{array}$ & $\begin{array}{l}\text { Paste A contained Diosmectite (DS) - } 80 \\
\mathrm{mg} / \mathrm{g} \text { and FGF2 - 10m g/g. Paste C (FGF2 }\end{array}$ & $\begin{array}{l}\text { Paste A (DS + FGF2) significantly reduced ulcer pain } \\
\text { scores and ulcer size. }\end{array}$ \\
\hline
\end{tabular}




\begin{tabular}{|c|c|c|c|c|c|}
\hline & stomatitis & & trial & paste) primarily contained FGF2 $(10 \mathrm{mg} / \mathrm{g})$ & \\
\hline FGF2 & $\begin{array}{l}\text { Periodontal } \\
\text { regenration }\end{array}$ & $\begin{array}{l}\text { Kitamura et } \\
\text { al., } 2011\end{array}$ & $\begin{array}{l}\text { Double blind, } \\
\text { randomised controlled } \\
\text { trial }\end{array}$ & $\begin{array}{l}0.2 \%, 0.3 \% \text {, or } 0.4 \% \text { FGF2 gel for local } \\
\text { application }\end{array}$ & $\begin{array}{l}\text { The periodontal fill was significantly higher in the FGF } 2 \\
\text { treated group. }\end{array}$ \\
\hline FGF2 & $\begin{array}{l}\text { Aphthous } \\
\text { ulcers }\end{array}$ & Ren, 2002 & $\begin{array}{l}\text { Randomised, double- } \\
\text { blinded, controlled } \\
\text { trial }\end{array}$ & $\begin{array}{l}\text { FGF2 spray ( } 300 \mathrm{AU} / \text { application, } 4 \\
\text { times/day) }\end{array}$ & $\begin{array}{l}\text { FGF2 significantly reduced the ulcer healing time in the } \\
\text { treatment group. }\end{array}$ \\
\hline FGF7 & $\begin{array}{l}\text { Oral mucositis } \\
\text { (Chemo- } \\
\text { radiotherapy) }\end{array}$ & $\begin{array}{l}\text { Goldberg et } \\
\text { al., } 2013\end{array}$ & $\begin{array}{l}\text { Retrospective } \\
\text { observational study }\end{array}$ & $\begin{array}{l}\text { Three daily doses of FGF7 ( } 60 \mu \mathrm{g} / \mathrm{kg} / \mathrm{day}) \\
\text { were given prior to transplant admission } \\
\text { with the third dose given no fewer than } 24 \\
\text { hours prior to administration of } \\
\text { chemotherapy or radiotherapy. Six hours } \\
\text { after stem cell infusion, patients received } \\
\text { three further daily doses of FGF7 ( } 60 \\
\mu \mathrm{g} / \mathrm{kg} / \mathrm{day}) \text {. }\end{array}$ & $\begin{array}{l}\text { FGF7 significantly reduced the number of days of total } \\
\text { parenteral nutrition, patient-controlled analgesia and } \\
\text { length of hospital stay in patients receiving total body } \\
\text { irradiation }\end{array}$ \\
\hline FGF2 & $\begin{array}{l}\text { Traumatic } \\
\text { perforations of } \\
\text { the tympanic } \\
\text { membrane }\end{array}$ & $\begin{array}{l}\text { Lou and } \\
\text { Wang, } \\
2013\end{array}$ & $\begin{array}{l}\text { Prospective, sequential } \\
\text { allocation, three-armed, } \\
\text { controlled clinical study }\end{array}$ & $\begin{array}{l}0.25 \mathrm{~mL}(4-5 \text { drops }) \text { of } \\
\text { FGF2 }(21,000 \mathrm{IU} / 5 \mathrm{~mL}) \text { solution }\end{array}$ & $\begin{array}{l}\text { Average closure time was significantly shorter in the } \\
\text { FGF2 application group. }\end{array}$ \\
\hline FGF2 & Pressure ulcers & $\begin{array}{l}\text { Robson et } \\
\text { al., } 1992\end{array}$ & $\begin{array}{l}\text { Randomised, blinded, } \\
\text { placebo-controlled trial }\end{array}$ & $\begin{array}{l}\text { FGF spray (concentrations of } 100 \mu \mathrm{g} / \mathrm{mL} \text {, } \\
500 \mu \mathrm{g} / \mathrm{mL} \text {, or } 1000 \mu \mathrm{g} / \mathrm{mL}\end{array}$ & $\begin{array}{l}\text { FGF2 resulted in a significantly higher number of } \\
\text { patients with } 70 \% \text { decrease in size of the ulcer in the } \\
\text { FGF2 treated group. }\end{array}$ \\
\hline FGF2 & Diabetic ulcer & $\begin{array}{l}\text { Uchi et al., } \\
2009\end{array}$ & $\begin{array}{l}\text { Randomised, double } \\
\text { blinded, dose-ranging, } \\
\text { placebo-controlled trial }\end{array}$ & FGF2 solution $(0.01 \%$ and $0.001 \% \mathrm{w} / \mathrm{v})$ & $\begin{array}{l}\text { Cure rates were significantly higher in the } 0.01 \% \mathrm{w} / \mathrm{v} \\
\text { FGF2 treated group. }\end{array}$ \\
\hline FGF2 & $\begin{array}{l}\text { Critical limb } \\
\text { ischaemia }\end{array}$ & $\begin{array}{l}\text { Kumagai et } \\
\text { al., } 2015\end{array}$ & Phase I-IIa trial & $\begin{array}{l}200 \mu \mathrm{g} \text { of FGF2 incorporated gelatin } \\
\text { hydrogel microspheres injected } \\
\text { intramuscularly into the ischemic limb }\end{array}$ & $\begin{array}{l}\text { Transcutaneous pressure, distance walked in } 6 \text { minutes, } \\
\text { rest pain scale and cyanotic pain scale showed significant } \\
\text { improvement at } 24 \text { weeks post-treatment with FGF2 as } \\
\text { compared to pre-treatment }\end{array}$ \\
\hline
\end{tabular}

